\title{
CHANGES IN ECONOMIC SENTIMENT INDICATORS BEFORE AND AFTER ECONOMIC CRISIS (POSITION OF VISEGRAD GROUP AND GERMANY IN EU)
}

Necadova, $M$.

Marta Necadova / University of Economics, Prague, Faculty of Business Administration, Department of Managerial Economics, W. Churchill Sq. 4, Prague, Czech Republic. Email: marta.necadova@vse.cz.

\begin{abstract}
Confidence factors play an important role not only in the assessment of business cycles but also in the evaluation of national competitiveness (e.g. the Global Competitiveness report published by the World Economic Forum) due to both using soft data obtained from opinion surveys. The subjective nature of confidence leads to questions about the soundness of such findings. Since the answers from opinion surveys are subjective, the empirical relationship between sentiment indicators and economic variables is not unambiguously established. In these conditions, the results of business surveys and the findings published by competitiveness rankings should not be accepted unconditionally. This paper starts with the comparison of soft data (respondents' sentiment) assessing the quality of institutions among world regions in the Global Competitiveness Report 2017-18. The aim of this paper is to offer a more precise view of the development of economic sentiment in the EU countries, especially in Germany and the Visegrad group countries (the V4). As tools for this description, a business sentiment indicator (ESI) and confidence indicators were applied. For analysis of changes in business sentiment and respondents' confidence, a graphical examination of variables, correlation analysis, changes in standard deviation, changes in countries' ranking, and the comparison of average sentiment (confidence) in the pre-crisis and the post-crisis period were used. Our analysis indicates the equivalent of the so-called halo effect in the pre-crisis period for the V4 (the positive expectation connected with the EU accession) and the deterioration in sentiment and confidence indicators in the post-crisis period.
\end{abstract}

Keywords: animal spirits, business sentiment, confidence indicators, economic sentiment indicator, Executive Opinion Survey, Global Competitiveness report, hallo effect, World Economic Forum

JEL Classification: E21, E32, M20 


\section{Introduction - cultural bias in survey data}

The publishers of the internationally respected rankings of national competitiveness (e.g., World Economic Forum - publisher of the Global Competitiveness Report) evaluate countries using composite indicators (the $\mathrm{Cl}$ ). For the construction of the final indicator, both hard and soft data are used ${ }^{1}$. The sensitivity of the final $\mathrm{Cl}$ on the quality and explanatory power of soft data depends on the representation of this type of data in the whole amount of the variables and on the statistical relevance of the opinion survey. The WEF's Executive Opinion Survey (the EOS) is considered an inestimable source, which can bring valuable information for private and public dialogue at the national and regional levels and help policymakers to focus on the critical barriers for a country's or region's competitiveness (Browne, Di Battista \& Geiger, 2016, p. 82). The EOS aims to monitor across time which areas of business can be particularly problematic for national competitiveness. This survey is administered by the World Economic Forum (WEF) and conducted at the national level by the WEF's network of Partner Institutes ${ }^{2}$.

The EOS, as a tool following the best international practices in surveying, is reviewed every year and its methodology has been audited by survey experts. Deeper audits were realized by Gallup in the years 2008 and 2012. The 2012 audit addressed an important aspect related to the impact of national culture (national sentiment) - the so-called cultural bias which can affect the interviewees' responses. The Global Competitiveness and Benchmarking Network admits that national sentiment can lead to bias "...however, following international best practices and upon Gallup's recommendation, it was decided not to re-weight the data using anchoring mechanisms because of the limited effectiveness of such a procedure and to prevent adding further noise to the data" (Browne, Geiger \& Gutknecht, 2013, p. 85). With the aim to mitigate cultural bias, the WEF's partner institutes are reminded to administer the EOS according to guidelines and to ask the respondents to answer the EOS "given the country they are assessing based on international comparison" (Browne et al., 2016, p.82). Nevertheless, the above-mentioned attitude of the WEF (not to re-weight the EOS soft data) can produce some unintended side effects - distortions, not only among individual countries but also among world regions (see Table 1 and the following text).

\footnotetext{
${ }^{1}$ Global competitiveness index (GCl) for the country is computed as a weighted average of 12 pillars: 1. Institutions, 2. Infrastructure, 3. Macroeconomic environment, 4. Health and primary education, 5. Higher education and training, 6. Goods market efficiency, 7. Labour market efficiency, 8. Financial market development, 9. Technological readiness, 10. Market size, 11. Business sophistication, 12. Innovation. The first five pillars are also referred to as basic requirements, the second five pillars are also designated as efficiency enhancers and the last two pillars are known as innovation and sophistication factors. The weights of the pillars depend on the stage of development of the particular economy.

${ }^{2}$ Most questions in the EOS ask respondents to evaluate, on a scale of 1 to 7 , one particular aspect of their operating environment. At one end of the scale, 1 represents the worst possible situation; at the other end of the scale, 7 represents the best. Partner Institutes include recognised research or academic institutions, business organisations, national competitiveness councils, or other established professional entities, and, in some cases, survey consultancies. The WEF's respondents include firms in proportion to the share of GDP accounted for by the sector, i. e. agriculture, manufacturing industry, non-manufacturing industry (mining and quarrying, electricity, gas and water supply, construction), and services.
} 
Table 1 | WEF respondents' assessment of the quality of institutions in a different world regions

\begin{tabular}{|l|c|c|c|}
\hline $\begin{array}{l}\text { Regions/pillar or sub-pillar } \\
\text { (hard/soft data) }\end{array}$ & $\begin{array}{c}\text { 1.Institutions } \\
\text { (0/21) }\end{array}$ & $\begin{array}{c}\text { 1A.Public } \\
\text { Institutions (0/16) }\end{array}$ & $\begin{array}{c}\text { 1B. Private } \\
\text { institutions (0/5) }\end{array}$ \\
\hline $\begin{array}{l}\text { Latin America and the } \\
\text { Caribbean }\end{array}$ & 3.36 & 3.21 & 3.82 \\
\hline Sub-Saharan Africa & 3.67 & 3.62 & 3.84 \\
\hline Visegrad Group countries & 3.74 & 3.62 & 4.10 \\
\hline Eurasia & 3.88 & 3.81 & 4.09 \\
\hline South Asia & 3.92 & 3.85 & 4.15 \\
\hline EU13 (new member countries) & 3.94 & 3.85 & 4.21 \\
\hline Middle East and North Africa & 4.34 & 4.35 & 4.34 \\
\hline EU28 & 4.53 & 4.46 & 4.72 \\
\hline Europe and North America & 4.55 & 4.49 & 4.74 \\
\hline East Asia and Pacific & 4.56 & 4.52 & 4.68 \\
\hline EU15 (old member countries) & 5.04 & 4.99 & 5.17 \\
\hline
\end{tabular}

Source: WEF (2017), own elaboration

In Table 1, we show the results of the assessment of the quality of institutions in the GCR 2017-18. The world regions are ranked according to the evaluation in the $1^{\text {st }}$ pillar - from the most negative to the most positive ${ }^{3}$. The WEF's traditional regional classification was broadened by a more detailed view of the EU28 countries (EU13 - the new member countries $^{4}$, EU15 - the old member countries, and the Visegrad group countries). It is clear that the critical attitude to the evaluation of institutions in the Visegrad group countries influences negatively not only the EU28 assessment (average value for this group of countries) in this WEF's pillar but also the average value for the EU13. Empirical studies using the WEF's results for the analysis of the V4 countries' competitive advantages or disadvantages confirm the results from Table $1^{5}$. In Europe, the sub-pillar of public institutions receives low scores in many Central and Eastern European countries (see the evaluation for the EU13). The critical attitude of respondents from the V4 countries is probably one of the reasons (or possibly the only reason) for the V4 and Sub-Saharan Africa gaining the same average value in the evaluation of public institutions. On the other hand, the predominantly positive evaluation of institutions in the old member countries ${ }^{6}$ has

\footnotetext{
${ }^{3}$ All sub-criteria included in this pillar are based exclusively on soft data. At the same time, this pillar contains the largest number of sub-criteria.

${ }^{4}$ The new member countries joined the EU at 2004 and later.

${ }^{5}$ E.g. Necadova and Soukup (2013) found that pillars based on soft data could act as substantial impediments to the improvement of the V4 national competitiveness. Similarly, papers dealing with the changes in WEF's evaluation of V4 countries after the economic crisis (e.g. Necadova, 2015) identify worse results (the deterioration in the ranking) in the pillars which are based exclusively or previously on soft data.

${ }^{6}$ Only respondents from countries with the important macroeconomic disbalancies, i. e. Greece $\left(89^{\text {th }}\right.$ position) and Italy ( $96^{\text {th }}$ position), were more critical to the quality of Public institutions than the Czech Republic (the best performer in this pillar from the V4).
} 
an evidently positive impact on the value for the whole EU and the region of Europe and North America.

From our point of view, regional comparison of the assessment of the quality of institutions in Table 1 raises the above-mentioned question about the explanatory power of soft data, which are distorted by the subjectivity of respondents. As Ochel \& Rohn (2006) point out, the necessary condition for comparability of survey results is using the same benchmarks for participants from all the countries compared. These authors also perceive the importance of the national specifics for the explanatory power of survey data and argue that the cross-country analysis cannot account for the specific characteristics of individual countries (e.g. the national sentiment). They note that the problem of countries' specifics becomes more pronounced (and the comparability decreases) as the sample of the countries included (and therefore their heterogeneity) increases. We can assume that in the international comparison of circa 140 countries (WEF's sample), the obtained results mirror the above-mentioned 'cultural bias', which can be connected with national sentiment ${ }^{7}$. As noted above, confidence (or sentiment) is an elusive concept, which cannot be defined precisely or measured directly. If we accept the current assumption of the international competitiveness rankings (that higher standards of living or higher GDP per capita are correlated with convenient results in all aspects of competitiveness), we can explain the discrepancy between the real standards of living and the self-assessment in soft data only by the above-mentioned specifics among countries (different national sentiment among countries). Since the WEF does not provide more detailed information about the differences among answers of respondents from the different branches and sectors of national economies, and the time series using the same EOS methodology is limited, we decided to use, in other parts of this paper, the survey data published by European Commission and Eurostat, which are published monthly, are available in a longer period than the WEF surveys and cover more homogenous samples of countries (the EU-28). The relatively long time series of the below-described survey data (time series of the economic sentiment and confidence indicators) enable us to compare not only the changes in the economic sentiment in the V4 during and after the economic crisis but also to evaluate the changes of sentiment connected with the EU accession.

\footnotetext{
7 The V4 country's positions in the $1^{\text {st }}$ pillar in WEF's group are the following: CZE (52.), POL (72.), SVK (93.), HUN (101.). (A slightly less pessimistic view of Polish and Czech respondents on the quality of private institutions is projected in these ranks: CZE (41.), POL (53.), SVK (78.), HUN (114.).) The comparison of above-mentioned results with the results of Sub-Saharan Africa could serve as a suitable argument promoting our assumption that the V4 countries evaluate themselves more pessimistically. Five Sub-Saharan countries - Rwanda (16.), Mauritius (37.), Namibia (44.), Botswana (45.), or Gambia (46.) - have better positions than the Czech Rep. (52.); the ranks of the other five SubSaharan countries - Ghana (59.), Cape Verde (65.), Senegal (67.), Lesotho (69.), or Tanzania (70.) -, are more favourable compared to Poland (80.); the institutions in Ethiopia (73.), Kenya (75.), South Africa (76.), Zambia (84.), Benin (91.), and Liberia (92.) are evaluated better than institutions in Slovakia (93.); Hungary (101.) is overtaken by,e.g. Malawi (96.), Uganda (99.) or Cameroon (100.)..Our summary is following: according to WEF"s ranking in the 1st pillar, 19 Sub-Saharan countries have better positions than Hungary.
} 


\section{Economic sentiment and confidence indicators - methodology and discussion}

\subsection{Measuring economic sentiment - methodology of the European Commission}

The Economic Sentiment Indicator (ESI) is comprised of 15 individual components of five confidence indicators. The explanatory power of the ESI is associated with the main aim of its construction - to summarise the attitudes and judgements of economic actors. The following explicit weights are allocated to different sectors to compute the composite indicator - Industry: $40 \%$, Services: $30 \%$, Consumers: $20 \%$, Construction: $5 \%$, Retail trade: $5 \%$. The given weights have been determined according to two criteria: 'representativeness' of the sector in question and tracking performance of the reference variable. The obvious reference variable is the GDP growth (the choice of this performance indicator is determined by the fact that GDP follows the movements of the economy as a whole). The weights mentioned above are not directly applied to the five confidence indicators themselves but to their standardised individual component series. Prior standardisation is essential to render the individual component series comparable in terms of both its mean level and volatility before aggregation, especially when the components pertain to developments in different sectors of the economy (European Commission, 2019, p. 23). The brief description of questions included in the monthly surveys is mentioned in Table 1 in the Annex. The sample size for each survey varies among countries according to the heterogeneity of their economies and is generally positively related to the countries' respective population size. Answers obtained from the surveys are aggregated in the form of 'balances'. Balances are constructed as the difference between the percentage of respondents giving positive replies and those giving negative replies. The European Commission (the EC) calculates the EU and euro-area aggregates using the national results and seasonally adjusts the balance series. The balance series is then used to build the composite indicators. Firstly, for each surveyed sector, the EC calculates the confidence indicators as arithmetic means of answers (seasonally adjusted balances). Secondly, the results for the five surveyed sectors are aggregated into the Economic Sentiment Indicator (ESI), whose purpose is to track the GDP growth in individual Member States, the EU, and the euro-area (European Commission, 2019, p. 10).

\subsection{Review}

According to a considerable amount of papers, economic sentiment indicators have limited explanatory and predictive power. Lemmens, Courx \& DeKimpe (2005) proved that the findings regarding the predictive power of the confidence indicators are mixed. According to these authors, the results strongly depend on whether an in-sample or out-of-sample testing framework is used. Similarly, Roberts \& Simon (2001) recommended caution when using sentiment indicators for analytical purposes. An investigation of the predictive power of component indices corresponding to the individual survey questions yields limited insight.

Posta \& Valenta (2011), describing the practice with the leading composite indicator at the MF CR (Ministry of Finance of the Czech Republic), encapsulated the critical criteria for the relevant predictive power of the indicators based on business surveys: economic 
interpretation, exhibition of cyclical behaviour, statistically significant relationship to the economic cycle, and time availability. Santero \& Westerlund (1996) used graphical examination, correlation analysis and Granger causality tests for examining the usefulness of consumer and business surveys in the assessment of the cyclical position of the economy and for forecasting output movements. Their key findings were the following: 1 . the relationship between sentiment indicators and output varies considerably across countries and sentiment measures, 2. for economic analysis, consumer confidence indicators are much less useful than business confidence indicators due to their much looser relationship with output movements. For example, Claveria, Pons \& Ramos (2007) (2007) analysed the explanatory power of 38 business and consumer survey indicators in the euro-area and pointed out some methodological problems with this type of survey data. Firstly, the information refers to the direction of change but not to its magnitude; secondly, the conversion of qualitative data into a quantitative measure enables the computation of only one-period-ahead forecasts. Sorić, Lolić \& Čižmešija (2016) and Gelper \& Coux (2010) proved that the methodology used in calculating ESI is potentially flawed because of arbitrarily chosen balance response weights. Gelper and Coux (2010) compare the original ESI with more sophisticated aggregation schemes (based on dynamic factor analysis and partial least squares) and show that alternative aggregation schemes bring stronger comovement of the composite indicator with economic activity and better forecast performance at longer horizons. Studies which are primarily concentrated on the explanatory power of indicators in times of economic turbulences bring ambiguous results. Analysis of Posta \& Pikhart (2012) shows that the turbulences in 2007-2008 had a detrimental impact on the relationship between ESI and GDP. Using rolling forecast and panel regression, the dependency of forecast errors on the magnitude of the quarterly changes in GDP was not proven. Therefore Posta \& Pikhart (2012) expected that the relationship between ESI and GDP may be exploited in relatively peaceful times while it may become quite distorted when the economy is hit by unexpected shocks.

In contrast, Throop (1992), who focused on consumer sentiment, found that consumer sentiment ordinarily has little complementary value in forecasting durables spending, yet when an unusual event occurs, the consumer confidence indicator is likely to improve forecasts. Similarly, Blanchard (1993) perceived the consumer confidence indicator as the bearer of relevant information mainly under circumstances of strong fluctuations in the economy. Neisingh \& Stokman (2013) found that the following factors have a major influence on the cyclical variations in the sentiment indicators: financial stability, price stability, and political stability in the given country.

Many studies inferred the assessment of predictive accuracy of the economic sentiment and the confidence indicators through bivariate, within-country Granger-causality tests, which resulted in mixed conclusions. Lemmens, Croux \& Dekimpe (2005) used both bivariate and multivariate Granger-causality tests to take into account cross-country influences. This approach results in the following consequences: the economic climate in Germany and France is found to influence the subsequent, actual production in the rest of the EU. The results of the multivariate analysis allow for the sorting out of EU countries according to influence and receptivity (France and Germany have more 'clout', while others are more 'receptive'). Therefore, Lemmens et al. (2005) support the harmonisation of EU business surveys as their approach allows for the exploitation of cross-country relations between different series of indicators which in turn leads to the improvement of forecasts of 
future account data for an individual country. Lemmens, Croux \& Dekimpe (2007) - using the concepts of dynamic correlation and cohesion between countries - investigated the homogeneity of EU countries in the consumer confidence indicators. Their findings are as follows: the short-run fluctuations in consumer confidence are found to be largely countryspecific; the consumer confidence indicators become much more homogeneous as the planning horizon is extended, and the homogeneity is inversely related to the economic and cultural distance among the various member states.

As we describe above, the economic and cultural distance among countries can cause the so-called national bias (Browne et al., 2013), which enters into the respondents' answers in the EOS and can cause a discrepancy between the economic performance and the respondents' sentiment. Studies concentrated on the impact of this phenomenon seek the reasons for 'irrational' consumers' decisions which are not explicable by variables of economic performance (i.e. income, inflation, unemployment). As Neisingh \& Stokman (2013) show, the academic literature is not unanimous about the added value of information on consumer confidence in comparison with other available broad economic indicators. In the academic discussion, there is no consensus on the existence of additional information contained in consumer confidence indicators compared to commonly used indicators of economic performance. Highlighting this is Ludvigson (2004) who points out that the mechanisms by which household attitudes influence the real economy are less well understood. Neisingh \& Stokman (2013) - on the Netherlands' example - identified three distinct types of drivers of consumer confidence: general economic indicators, animal spirits, and trust. According to them, the financial crisis caused the loss of faith in the financial system in Europe and contributed to the longer-lasting negative impact on consumer confidence and spending.

The term 'Animal spirits' was first used by Keynes (1973) in Chapter 12 of The General Theory of Employment, Interest, and Money, 'The State of Long-Term Expectation', with the aim to explain human action in relation to asset prices. Keynes wrote that when individuals cannot make a rational calculation of expected values, animal spirits are the de facto springs of action. He defined 'animal spirits' as 'a spontaneous urge to action rather than inaction' (Keynes, 1973, p. 161). According to Koppl (1991), Keynes connects the term with irrational behaviour. On the contrary, Camerer, Loewenstein \& Rabin (2004) argued that if only limited time and limited knowledge are available, cognitive capabilities using intuition, rules of thumb, and heuristics may be considered rational. Santero \& Westerlund (1996) considered 'animal spirits' to be the most explicit reference to business sentiment in the business cycle theory, which is used to explain the volatility of private business investment spending. According to them, it is unclear what specifically these animal spirits are, and the shifts in sentiment were left largely unexplained. (Santero \& Westerlund, 1996, p. 5). Neisingh \& Stokman (2013) perceived animal spirits as manifestations of overly optimistic or pessimistic perceptions on the part of households which in consequence desire to consume more or less than is optimal in conditions of perfect information. Blanchard's interpretation of the term is connected with "increasing prudence to changes in intertemporal preferences, to the sudden realization of past over borrowing, panic and so on," (Blanchard, 1993, p. 274). According to Katona (1951), consumers' ability (objective financial resources) and willingness (their subjective perception of the world) are the key factors for their decisions. Therefore, even if negative shocks do not have a direct impact on consumers' ability-to-buy, they might affect consumers'willingness-to-buy. Neisingh and 
Stokman (2013) assumed that the development of the stock market and the yield spread affect willingness-to-buy and overall consumer confidence. They estimated that a relation between stock market developments (and the yield spread) and overall consumer confidence exists. Economic optimism based on the expectation of positive institutional changes and positive future economic performance connected with entry to the EU is perceived as the background for the explanation of the so-called 'halo effect'.

Cihak \& Mitra (2009) analysed spreads on the sovereign bonds of new member states in the period 2005-08 and searched for the causes for the differences in spreads in the precrisis period and during the crisis. They showed that the crisis has led to the disappearance of the 'halo effect'. This term is used for the designation of the difference between the fundamental and actual sovereign bond rates. According to Hauner, Jonas \& Kumar (2007), the EU halo effect is linked to EU membership and arises from the optimism associated with perceived better institutions and processes (such as fiscal rules) compared to those present before entry to the EU. In the pre-crisis period, despite fundamentals, the positive perception of these institutional improvements in the new member states probably had the effect of reducing sovereign risk $^{8}$. Jansen \& Nahuis (2003) observed the importance of fundamentals in the decision-making processes in the financial markets. They found that the decisions made in the stock markets are driven by expectations about economy-wide conditions rather than personal finances.

\section{Economic sentiment and confidence indicators - analysis}

\subsection{Aims of analysis}

We aim to offer a more precise view of the changes of economic sentiment inside the EU and, above all, the V4 countries. Eurostat and National Statistical Offices, which publish results of relevant surveys on a monthly basis, served as a suitable source of relevant data about economic sentiment and confidence. In this part of the paper, we analyse the changes of ESI (Economic Sentiment Indicator) and confidence indicators in the period 2002Q2 - 2016Q4. This period enables us to follow changes in sentiment for the V4 countries and the majority of the EU countries. We note that the length of time series captured in the charts depends on the availability of survey data for the V4 and Germany.

Our analysis seeks the answers to the following questions:

- Is it possible to identify positive/negative economic sentiment in the V4 countries in connection with entry to the EU and the economic crisis? Can we identify more significant changes in the economic sentiment of the V4 countries before and after the economic crisis?

- Can we observe the changes in the relationship (in correlation) between ESI (or given confidence indicator) and GDP in the pre-crisis and the post-crisis period?

\footnotetext{
${ }^{8}$ Cihak and Mitra (2009) also illustrated the increased country dispersion of sovereign spreads during the crisis and demonstrated that this t can be, in no small part, explained by the differences in the macroeconomic performance and external vulnerabilities of the countries (success in keeping inflation low and the financing of the current account deficit at a sustainable level).
} 
- Are the V4 countries - according to the changes in ESI and in confidence indicators in both periods - a more homogeneous or heterogeneous group of countries?

\subsection{Methods}

The homogeneity of the V4 will be evaluated using the frequency distribution and descriptive statistics for all indicators. To examine the rate of coincidence among indicators of Germany ${ }^{9}$ and the V4 countries, graphs with quarterly values for the above-mentioned countries will be presented. Additionally, the graphical examination enables the monitoring of the impact of economic crises on the changes in confidence indicators. The assessment of the relationship between business sentiment indicators and GDP is based on the analysis of correlation coefficients of the confidence indicator with GDP growth. Following the approach of Santero \& Westerlund (1996), the number of quarter lags reported was limited to four lags since the highest correlation was found within one to four quarters after the observation point in time (see Tables $3 a$ and $3 b$ in Annex). Following these authors, a correlation coefficient exceeding 0.75 is considered as large in our commentaries. In our analysis, these other methods were applied. Firstly, the ranking of the EU member states according to the average value of individual indicators (see Tables in Annex) for three-time series was constructed. The following time series were considered: 1) the whole period (2002Q2 - 2016Q4), 2) the $1^{\text {st }}$ period $(2002 Q 2-2009 Q 4)$, and 3) the $2^{\text {nd }}$ period $(2010 Q 1-$ 2016Q4). Secondly, the graphs with difference between the average values in the $1^{\text {st }}$ and the $2^{\text {nd }}$ period are considered to be a suitable tool for the assessment of the impact of the economic crisis on economic sentiment. The graphs with the above-mentioned differences are added by standard deviations of variables in both periods with aim to describe the differences in variability among the EU member states and compare the changes in variability in both periods.

\subsection{Economic sentiment indicator (ESI)}

The graphical examination in Figure 1 highlights the impact of the transformation recession on the economic sentiment in the V4 countries; deeper deterioration is visible in the Czech and Slovak Republic. The process of entry to the EU is likely connected with bigger optimism in these countries compared to Germany which at the time of its entry to the EU in the '90s was influenced by the process of equalization of economic and living standards among old and new federal states.

${ }^{9}$ Germany was chosen for comparison with the V4 countries as their closest and strongest trade partner. 


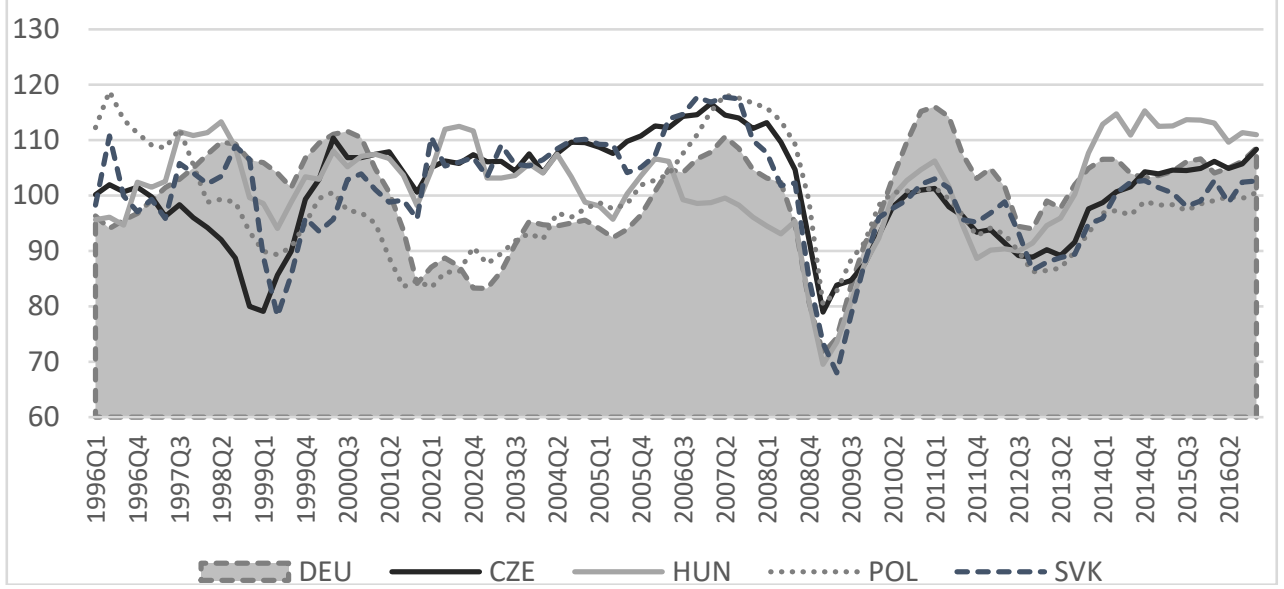

Source: Eurostat (2018), own elaboration

The analogue between the ESI values and the halo effect (see Cihak \& Mitra, 2009) is evident from the comparison of the V4 with Germany in the period 2002Q1-2008Q1. The earlier deterioration of the Hungarian ESI compared to the other V4 countries is connected with macroeconomic imbalances as Hungary suffered from a large fiscal deficit, high inflation, and external debt. In the post-crisis period, the economic sentiment in the Czech and Slovak Republic and Poland has been more negative compared to Germany and the other EU countries. The most positive economic sentiment in Hungary in the period 2013Q3-2016Q4 was connected with the economy-wide conditions, especially relatively high economic growth which, according to the average quarterly growth rate of GDP, ranked $15^{\text {th }}$ in the post-crisis period among Germany and other EU countries.

Figure 2 | ESI_frequency distribution (average value of ESI, 2002Q2-2016Q4) ${ }^{10}$

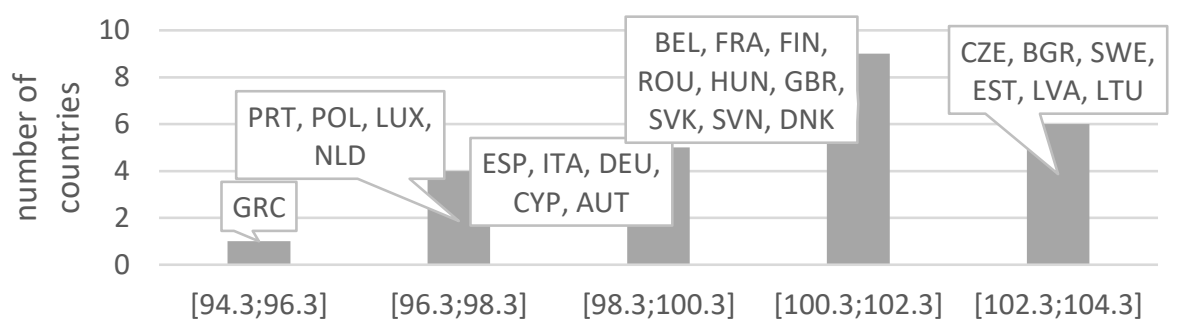

Source: Eurostat (2018), own elaboration

\footnotetext{
10 The frequency distribution in this paper is presented as a frequency bar chart. This method provides a visual display using columns, with the $y$-axis representing the frequency count (the number of countries) and the $x$-axis representing the variable to be measured (the average value of indicators in the whole period, i.e 2002Q2 - 2016Q4). The individual column's legend indicates which countries are included in a given quantile. Reading the legends from right to left allows to follow the EU ranking according to the average value of the given indicator.
} 
Despite the deterioration of the average value of ESI in the post-crisis period, the Czech position ( $6^{\text {th }}$ place) is the best in the whole period. Positive sentiment in the new member states in the first period contributes to their position in the first half of the EU countries (with the exception of Poland, which occupies the $23^{\text {rd }}$ place). Polish economic sentiment was below the EU average, but was relatively stable during the whole period.

Figure 3 | ESI_differences between periods

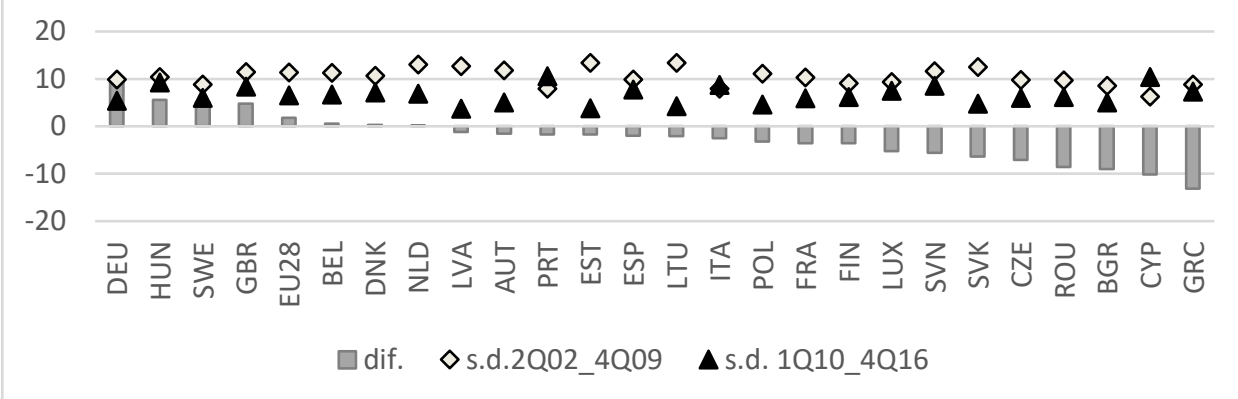

Source: Eurostat (2018), own elaboration

The stronger negativism after the crisis is linked with the bigger sensitivity of small open economies in the economic cycle. This pesimism determined the negative changes of Czech and Slovak ranking (from the $2^{\text {nd }}$ to the $11^{\text {th }}$ position for the Czech Republic and from the $6^{\text {th }}$ to the $18^{\text {th }}$ place for the Slovak Republic) - see Table2a in Annex. The improvement in the post-crisis period was observed only in four countries. The highest positive difference for Germany is connected with a change in the EU ranking according to average ESI value during the whole period by 23 places (from $25^{\text {th }}$ place to $2^{\text {nd }}$ place). Simultaneously, Germany is the country with a relatively stable development of ESI (standard deviation is below the EU average), and higher variability in the post-crisis period was found only in Greece, Italy, Cyprus, and Portugal (i.e. in countries with bigger macroeconomic imbalances). The higher prudence (connected with the smaller average of the indicator) and the lower variability after the crisis are typical for the majority of the EU countries. Table $3 a$ in the Annex shows the best results for the correlation coefficients between ESI and quarterly GDP growth. Changes of ESI matched GDP swings with a lag of one quarter in the whole period (2002Q2-2016Q4) in the Czech Republic (with the closest relation from chosen countries in all periods), Hungary, Slovakia, and Germany. Higher coefficients are found in the pre-crisis period. The weakest relationship and better results for the second lagged value of ESI are observed in Poland. Stronger correlation is typical for the pre-crisis period (with the exception of Poland). Tendency to a more pessimistic attitude of respondents after the economic crisis should explain the more significant correlation at the second lag of ESI during the post-crisis period. These results imply that ESI should not be considered as a reliable leading indicator in our countries' sample.

\subsection{Consumer confidence indicator $(\mathrm{CCl})$}

Graphical examination of $\mathrm{CCl}$ in Figure 4 implies the prevailing pessimism of consumers during the whole period with the most negative balances occurring during the economic crisis. Positive balances were registered only in the Czech Republic and Germany. Czech consumers' optimism (slightly positive balances) is observable during the pre-crisis years 
(2006-07) and at the end of the period (2015-16). In Germany, the predominance of positive answers is visible during the year 2007 and in the time of recovery after the economic crisis - in the period 2010Q2-2011Q3. The strongest negativism in Hungary is connected with the above-mentioned macroeconomic misbalances and the only belowaverage quarterly GDP growth - compared to other NMC - during the whole period (14 $4^{\text {th }}$ place - see Table 2a in Annex).

Figure 4 | CCl_Germany, V4 (2001Q1-2016Q4)

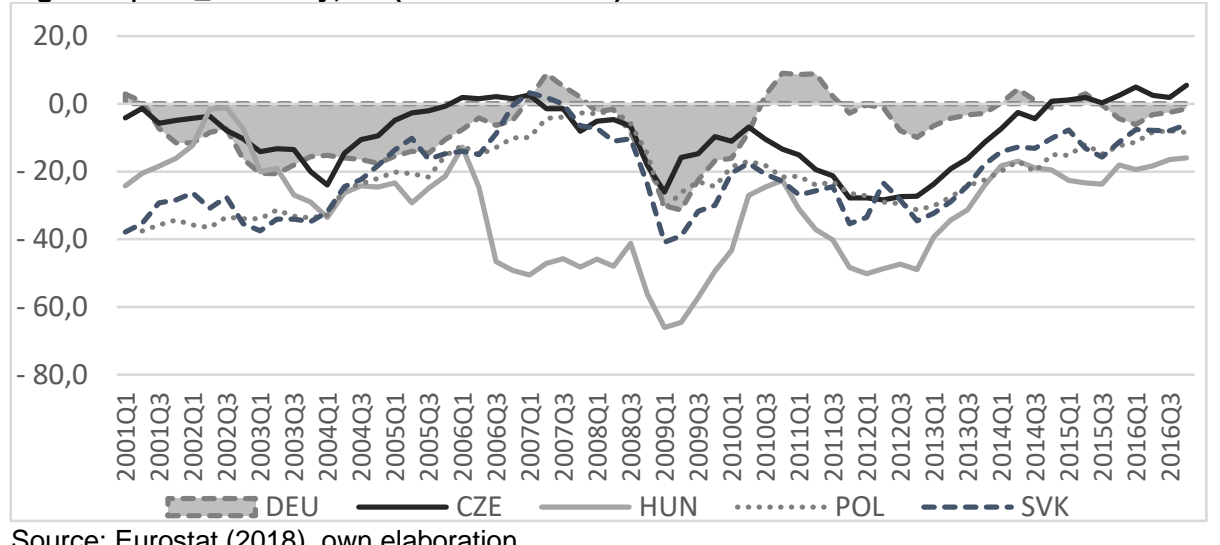

Source: Eurostat (2018), own elaboration

The prevalence of positive consumer perception (according to the average value for the whole period) was monitored only in these three EU countries: Finland, Sweden, and Denmark (see Figure 5).

Figure 5 | CCI_frequency distribution (average value of CCI, 2002Q2 -2016Q4)

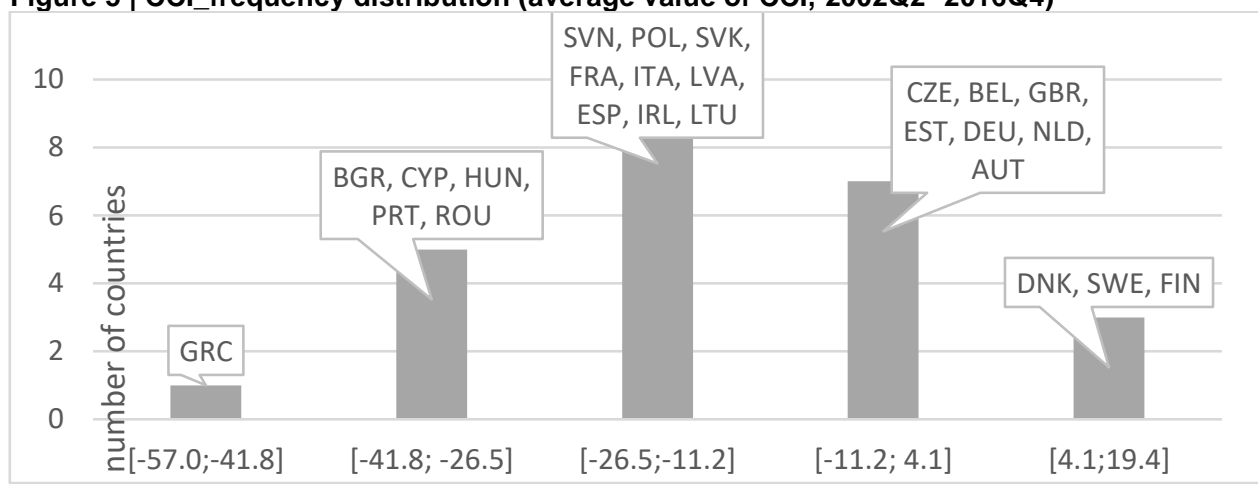

Source: Eurostat (2018), own elaboration

In the first period, the mean of $\mathrm{CCl}$ is lower than the median in the Czech Republic, Hungary, and the Slovak Republic, which implies the left-skewness of $\mathrm{CCl}$. The occurrence of positive outliers has an influence on the right-skewness of $\mathrm{CCl}$ for Germany and Poland. In the post-crisis period, it is possible to monitor the lower rate of consumers' pessimism on average in Germany, Hungary, Poland, and Slovakia. The Czech Republic is one of the 16 member countries where pessimism has grown in the post-crisis period (see Figure 6). In 
the post-crisis period, the values of $\mathrm{CCl}$ are more variable in the 18 member states (see Figure 6).

Figure 6 | CCl_differences between periods

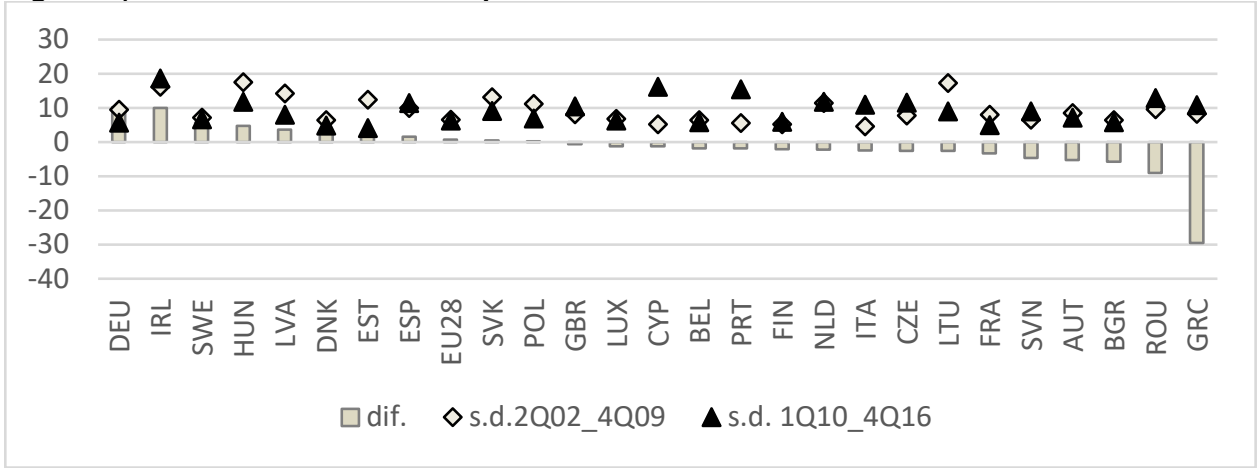

Source: Eurostat (2018), own elaboration

More negative (in 16 member states) and volatile consumer sentiment is connected with the negative impacts of the economic crisis in the form of the above-mentioned higher vulnerability of countries with macroeconomic imbalances (Cyprus, Portugal, Greece, Spain). From the V4 countries, Czech respondents were more pessimistic only in the postcrisis period. Higher Czech negativism explains the lack of two places in $\mathrm{CCl}$ ranking (see Table 2a in Annex). Despite this fact, the average value of the Czech's $\mathrm{CCl}$ is the highest compared to the other V4 countries (10 $10^{\text {th }}$ place of the Czech Republic in comparison with the $15^{\text {th }}$ place of the Slovak Republic, the $16^{\text {th }}$ position of Poland, and the $20^{\text {th }}$ rank of Hungary). The biggest positive change of average consumer sentiment between the precrisis and the post-crisis period was observed in Germany. This change is reflected in the better position of Germany in $\mathrm{CCl}$ ranking (the shift from $10^{\text {th }}$ to $4^{\text {th }}$ place).

As Table 3a (in Annex) shows, the relationship between GDP and $\mathrm{CCl}$ is weaker compared to the relationship between GDP and ESI. Changes of CCI matched GDP swings with a lag of one quarter for all periods. Higher coefficients are found in the pre-crisis period. The weakest relationship is monitored in Poland. Closer correlation is registered in the pre-crisis period - with the exception of the Czech Republic (there is a significant correlation at the second lag). A comparison of correlation coefficients (see Table $3 a$ in Annex) shows that correlation between $\mathrm{CCl}$ and GDP is weaker than the correlation between ESI and GDP. As Santero \& Westerlund (1996) state, $\mathrm{CCl}$ is probably more easily affected by factors unrelated to near-term business cycle fluctuations (i.e. animal spirits, cultural bias, etc.).

\subsection{Construction confidence indicator (Constr. $\mathrm{Cl}$ )}

The prevalence of negative balances in respondents' answers is typical for construction confidence indicator in the V4 and Germany (see Figure 7). Compared to the average confidence of EU28 (see Table 9 in Annex), the above-average confidence in the precrisis period was found in the Czech Republic and in the post-crisis period in Germany. 


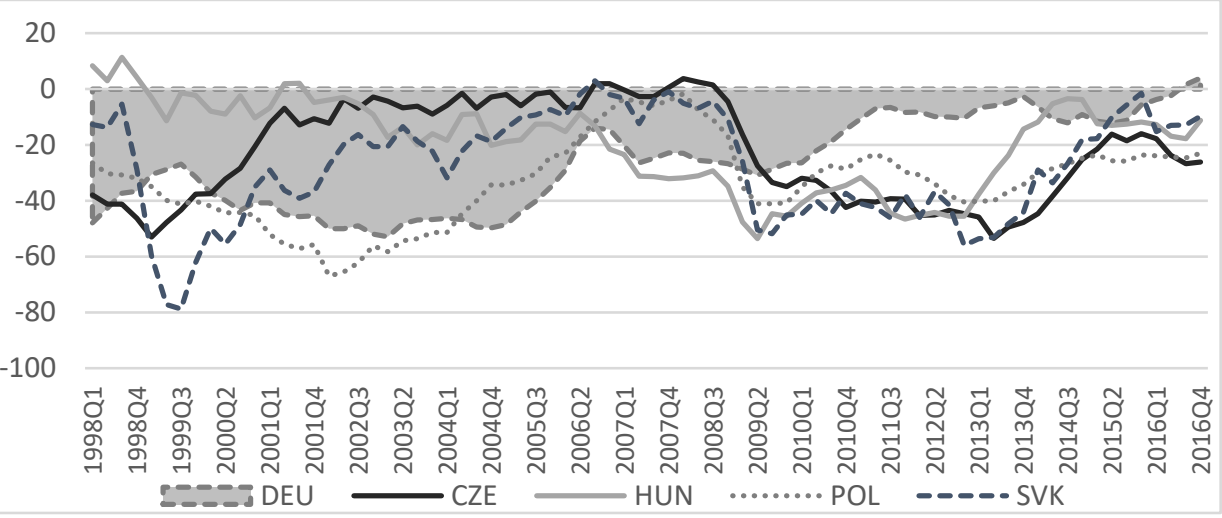

Source: Eurostat (2018), own elaboration

In the first period, the less negative balances in the V4 compared to Germany are connected with the inflow of FDI and consequential higher activity in construction. The lower inflow of FDI along with the realisation of the higher vulnerability of small opened economies in the post-crisis period can explain the higher pessimism in the Czech Republic, Hungary, and Slovakia. As Figure 9 shows, in the post-crisis period, the lower average pessimism in construction was observed only in five EU countries (Germany, Luxembourg, Austria, Sweden, and Poland).

Figure 8 | Constr.Cl_frequency distribution (average value of Constr. Cl, 2002Q2_2016Q4)

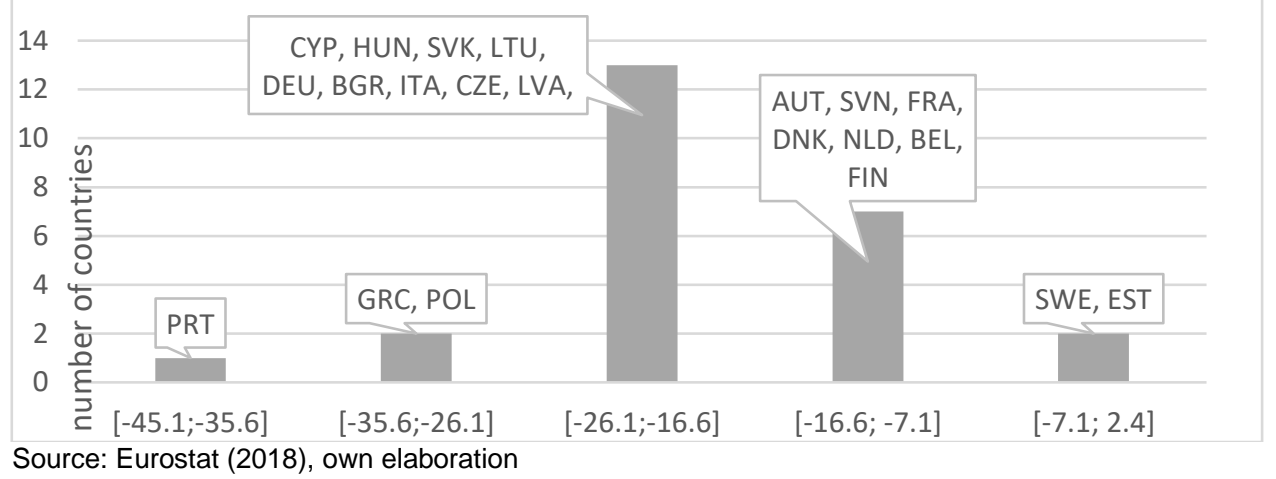

According to the average value for the whole period, the smallest pessimism in construction was monitored in Estonia and Finland. In the first period, the mean of Constr.Cl is lower than the median in the Czech Republic, Hungary, Germany, and the Slovak Republic, which implies the left skewness of their Constr.Cl. The occurrence of less negative outliers compared to positive has resulted in the slightly right skewness of Constr.Cl for Czech Rep., Hungary, and Slovakia (see descriptive statistics in Table 9 in Annex) in the postcrisis period. In this period, it is possible to monitor lower variability in the majority of EU countries - but the Czech Republic, Slovakia and Hungary are in the group of six countries with bigger swings in construction. The relatively high increase of pessimism in the Czech 
Republic and Slovakia affects their position in ranking (the change from the $8^{\text {th }}$ to $21^{\text {st }}$ rank for the Czech Rep. and from the $19^{\text {th }}$ to $20^{\text {th }}$ place for Slovakia).

Figure 9 | Constr.Cl_differences between periods

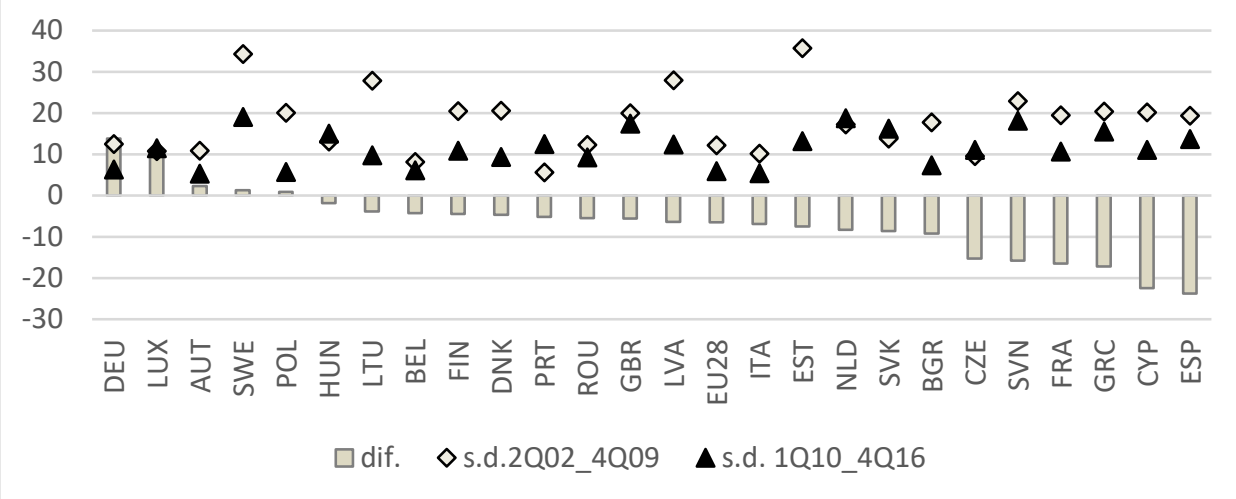

Source: Eurostat (2018), own elaboration

As Table 3b (in Annex) shows, the relationship between GDP and Constr.Cl is weaker compared to the relationship between GDP and ESI. The closest correlations were observed at the second lag of Constr. $\mathrm{Cl}$ with exceptions in all three periods. E.g., in the case of the Czech Republic there is a more significant correlation between the third lag of sentiment indicator and GDP, while the fourth lag of Constr. $\mathrm{Cl}$ is closer related to GDP than other lags for Germany and Poland. Higher coefficients are mostly found in the precrisis period (after the economic crisis, higher correlation was observed only in case of Poland and Slovakia).

\subsection{Industrial confidence indicator (ICI)}

Czech and Slovak respondents show the most significant rate of confidence in the evaluation of the present situation and future development in industry and services, strongly positive balances are typical for the Czech sentiment in retail and services as well. The optimism of Czech and Slovak respondents from industry is evident in comparison with the other V4 countries and Germany (see Figure 10). The prevalence of positive balances makes Czech's and Slovak's respondents leaders in $\mathrm{ICl}$ within the $\mathrm{EU}$ during the whole period.

The graphical examination in Figure 10 reveals the following tendencies in the post-crisis period: lower average optimism in the Czech Republic and Slovakia, lower average pessimism in Germany and Hungary, and higher inclination to negativism of Polish respondents.

The differences in industrial sentiment within the V4 countries are apparent from the frequency distribution in Figure 11. 


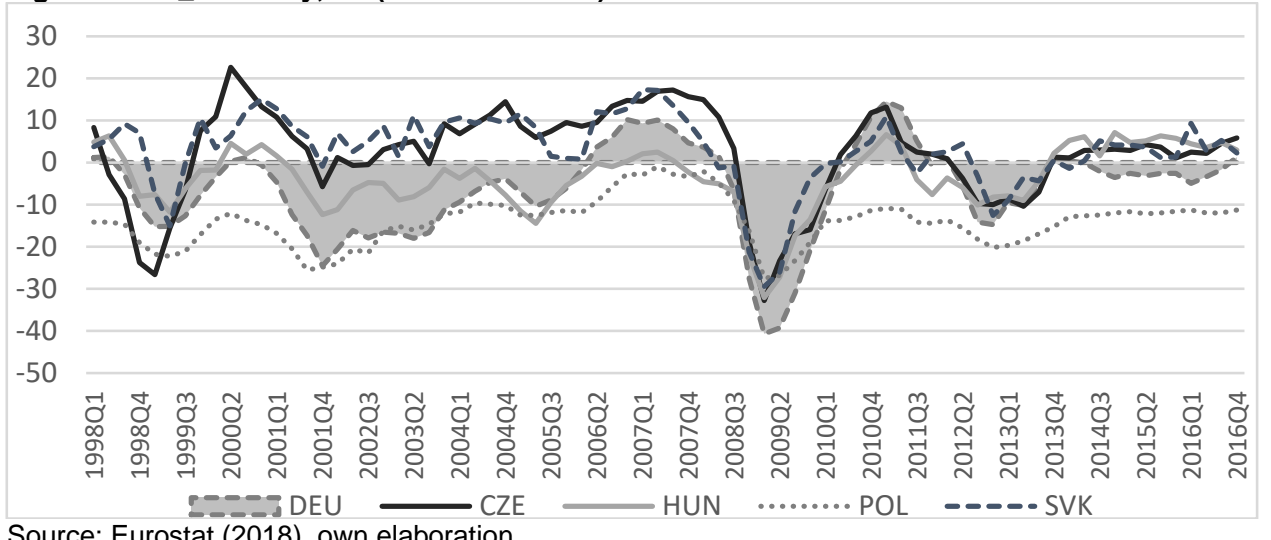

Source: Eurostat (2018), own elaboration

Figure 11 ICI_frequency distribution (average value of ICI, 2002Q2-2016Q4)

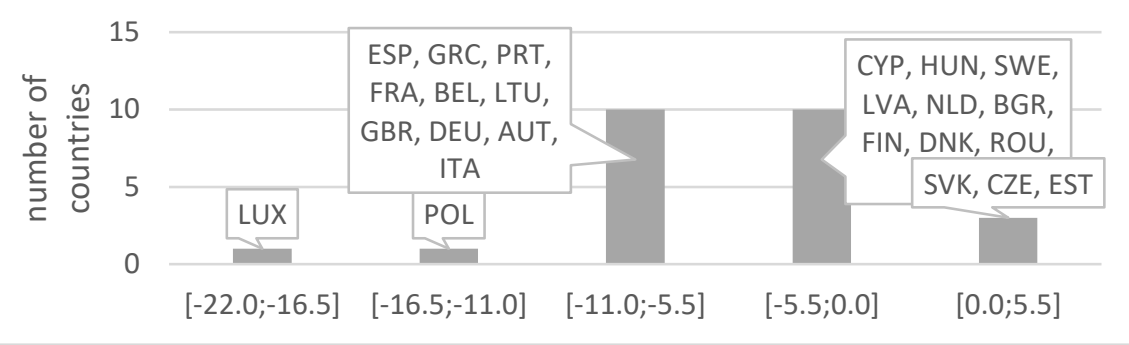

Source: Eurostat (2018), own elaboration

While the Czech and Slovak Republic are the EU leaders in the average optimism, Polish respondents belong to the biggest pessimists. This fact is naturally related to the different structure of the Polish economy and follows the different orientation of Polish competitive advantage in foreign trade. Differences in industrial sentiment within the V4 countries are also apparent from the frequency distribution in Figure 11.

Figure 12 | ICI_differences between periods

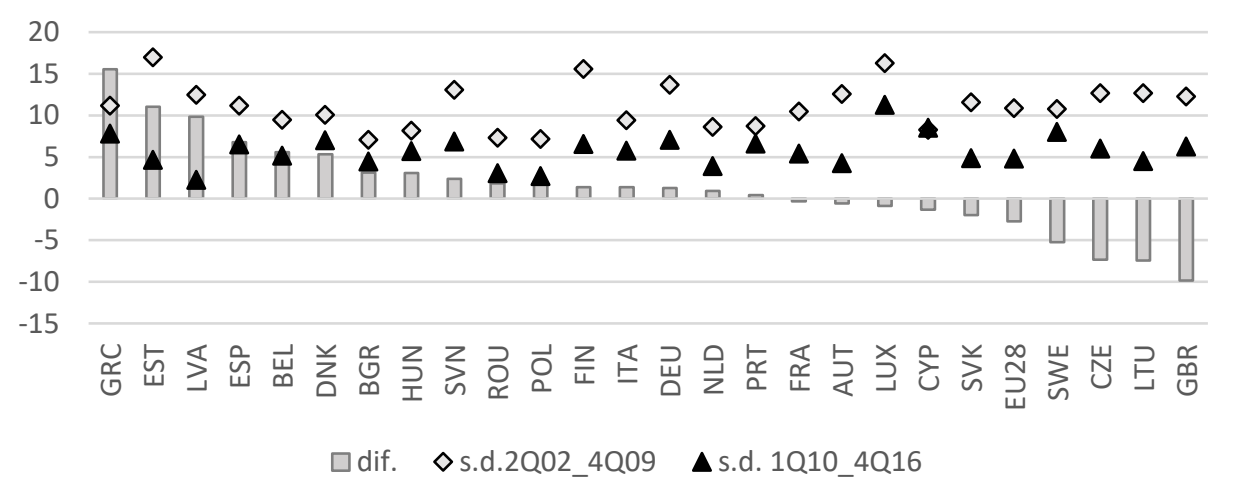

Source: Eurostat (2018), own elaboration 
As Figure 12 shows, the negative changes in average industrial sentiment were observable in $10 \mathrm{EU}$ countries in the post-crisis period. Despite the relatively high decrease of Czech and Slovak optimism, both countries have stayed as leaders in the $\mathrm{ICl}$ ranking (the Czech Republic is in the $2^{\text {nd }}$ position in both periods, the Slovak Republic improved its position by two places - from the $3^{\text {rd }}$ to the $1^{\text {st }}$ rank). The positive shifts in ranking for Hungary (from the $17^{\text {th }}$ to $4^{\text {th }}$ place) and Germany (from the $22^{\text {nd }}$ to $9^{\text {th }}$ position) are caused by lower pessimism in the post-crisis period. The more significant negative changes of balances compared to positive swings are the reason for left skewness of $\mathrm{ICl}$ for all V4 countries and Germany (see descriptive statistics in Table 7). In the post-crisis period, it is possible to monitor the lower variability in all EU countries. This tendency is connected on one hand with lower pessimism in the EU generally, but on the other hand with lower optimism on the side of leaders. Table $3 a$ (in Annex) shows that changes of ICI have matched GDP swings with a lag of one quarter in the pre-crisis period (with the exception of Poland) and with the lag of two quarters after the economic crisis. The closest relationship for the Czech Republic is found in both periods. The lagged ICI is closely correlated with GDP in the precrisis period (with the exception of Poland).

\subsection{Retail confidence indicator $(\mathrm{RCl})$}

Positive balances in Czech answers and mostly positive balances in Slovak retail confidence (only the period 2009Q1 - 2010Q2 is connected with negative balances) indicate the confidence in the evaluation of the present situation and future development in retail. This optimism of Czech and Slovak respondents is evident in comparison with Hungary, Poland, and Germany (see Figure 13).

Figure 13 | RCI_Germany, V4 (1996Q1-2016Q4)

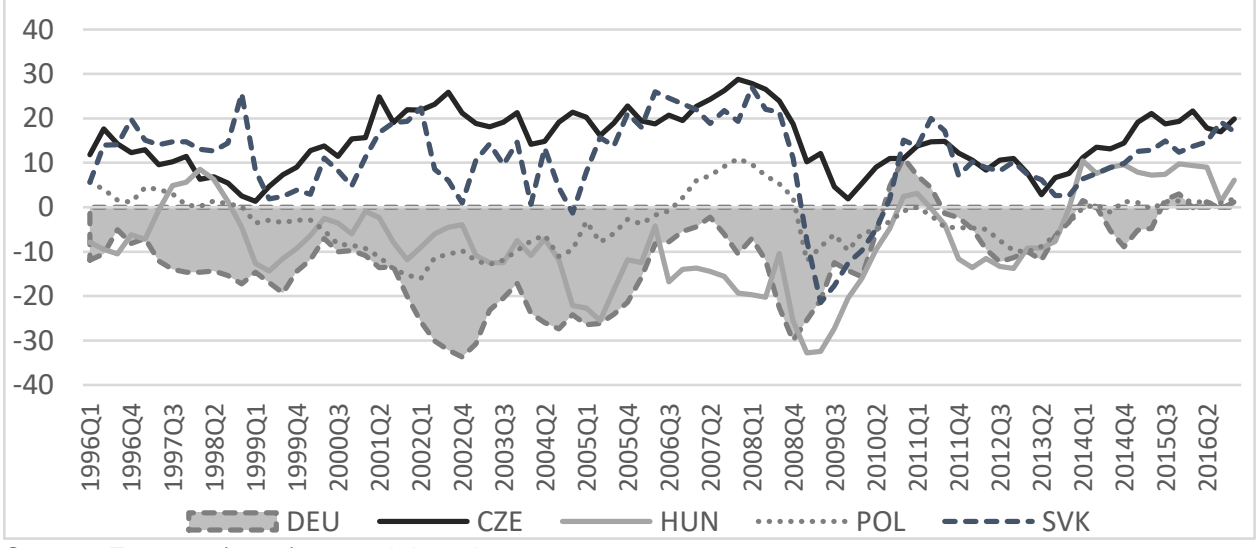

Source: Eurostat (2018), own elaboration

The lower Czech optimism during the year 2013 is connected with the negative sentiment caused by the so-called second recession. Graphical examination in Figure 13 indicates the following tendencies in the post-crisis period: lower average optimism in the Czech Republic, slightly lower optimism in Slovakia, bigger decrease of pessimism in Germany, and slightly lower pessimism in Poland. 
Figure 14 | RCl_frequency distribution (average value of $\mathrm{RCl}, 2002 \mathrm{2}-2016 \mathrm{Q}$ )

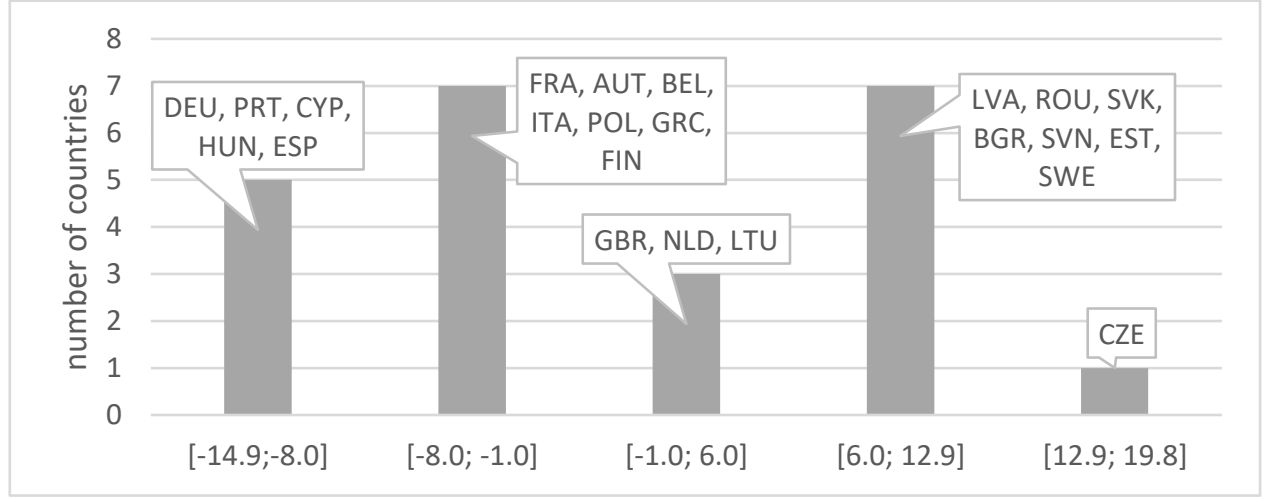

Source: Eurostat (2018), own elaboration

Positive Czech and Slovak evaluation of present and expected development in retail affect the EU ranking for the whole period (see Figure 14 and Table $2 b$ in the Annex). The differences in retail sentiment within the V4 countries are apparent from the frequency distribution in Figure 14. While the Czech and Slovak Republic are the EU leaders in the average optimism in retail, Hungarian respondents - due to the above-mentioned pessimism caused by macroeconomic imbalances - belong to the biggest pessimists in the EU28.

\section{Figure 15 | RCI_differences between periods}

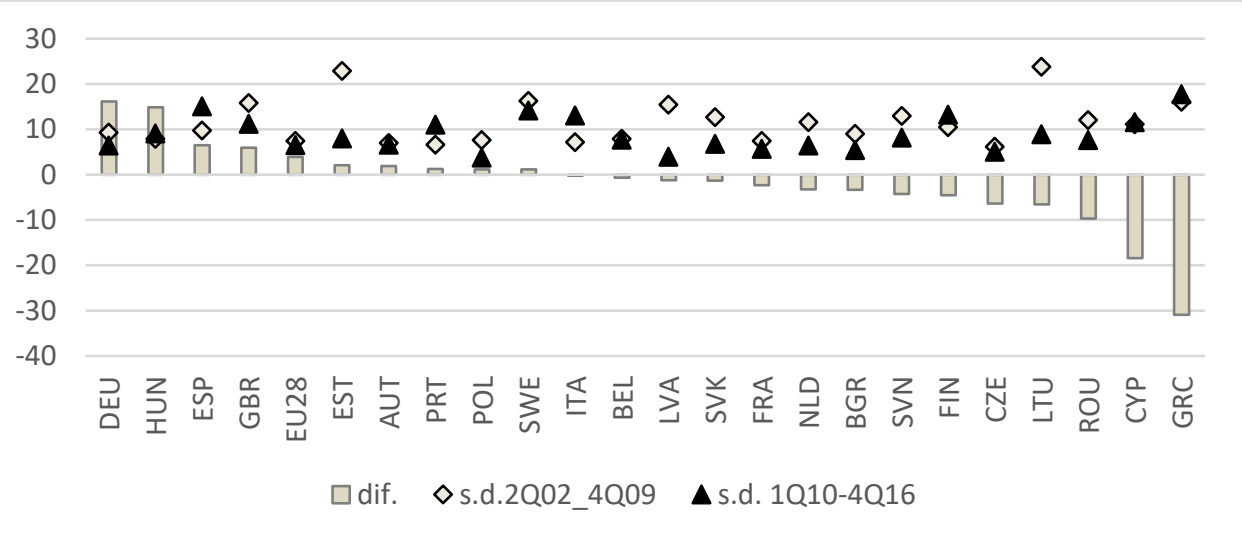

Source: Eurostat (2018), own elaboration

As Figure 15 shows, the negative changes in average retail sentiment were observable in 14 EU countries in the post-crisis period. Despite the relatively high decrease of Czech optimism, the Czech Republic has stayed the leader in $\mathrm{RCl}$ ranking (the position of Czech Republic is worsened by one place between the pre-crisis and the post-crisis period - from $1^{\text {st }}$ to $2^{\text {nd }}$ place), the Slovak Republic improved its position by three places - from $7^{\text {th }}$ to $4^{\text {th }}$ rank). The positive shifts in ranking for Hungary (from the $22^{\text {nd }}$ to the $12^{\text {th }}$ place) and Germany (from the $23^{\text {rd }}$ to the $14^{\text {th }}$ position) are caused by lower pessimism in the postcrisis period. The bigger negative changes of balances compared to positive swings are the 
reason for the left-skewness of $\mathrm{RCI}$ for Hungary and Slovakia during the pre-crisis period (see descriptive statistics in Table 8 in Annex). In the post-crisis period, it is possible to monitor the lower standard deviation of $\mathrm{RCI}$ in Germany, in the EU28, and in all the V4 countries (with the exception of Hungary). The decrease of pessimism in Hungary and the positive value of median in the post-crisis period are connected with the slightly higher variance of $\mathrm{RCl}$. The negative average values of $\mathrm{RCl}$ for the EU28 as a whole are caused by pessimism in the old member countries, in the EU19 respectively (see Table 8 in the Annex).

Table $3 \mathrm{~b}$ in the Annex shows that the number of RCl's lags (behind the changes in GDP) varies among countries. The biggest number of lags and relatively tight relation between sentiment indicator and GDP is observed in the Czech Republic in both periods (RCl lagged four quarters behind GDP swings before crisis, the third lagged value of $\mathrm{RCl}$ was relatively well correlated with GDP in the post-crisis period). The weakest relationship was observed in Poland. It is obvious that RCI and GDP are correlated closely in the pre-crisis period.

\subsection{Service confidence indicator (SCl)}

Positive balances in Czech answers and mostly positive balances in Slovak service confidence in services (only these periods: 2009Q1 -2009Q3, 2012Q3 - 2013Q4, 2015Q12016Q1 and 2016Q3 were connected with the slightly negative balances in Slovakia) indicate the confidence in the evaluation of the present situation and future development in services. This optimism of Czech and Slovak respondents is evident compared to Hungary, Poland, and Germany (see Figure 16).

Figure 16 | SCl_Germany, V4 (2002Q2-2016Q4)

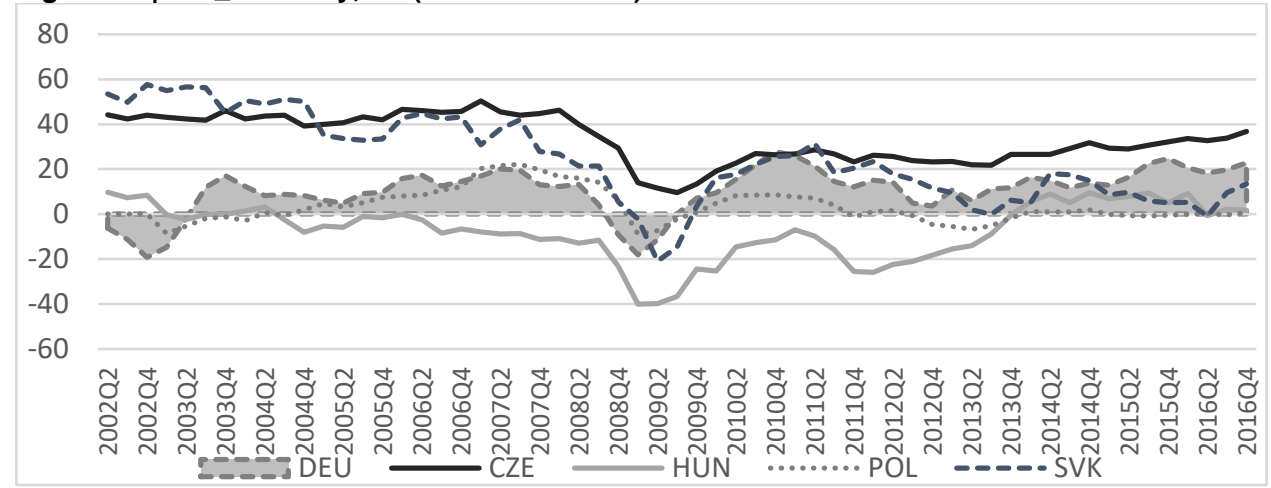

Source: Eurostat (2018), own elaboration

Figure 16 shows that the similar rate of optimism of Czech, Slovak, and German respondents is observable only during the crisis. A slight decrease of Czech optimism during the year 2013 is connected with higher stability of this sector during the crisis periods compared to other economic areas. The graphical examination in Figure 16 indicates these tendencies in the post-crisis period: lower average optimism in the Czech Republic, Slovakia, and Poland, decrease of pessimism in Hungary, and higher optimism in Germany. 
Figure 17 | SCI_frequency distribution (average value of SCI, 2002Q2-2016Q4)

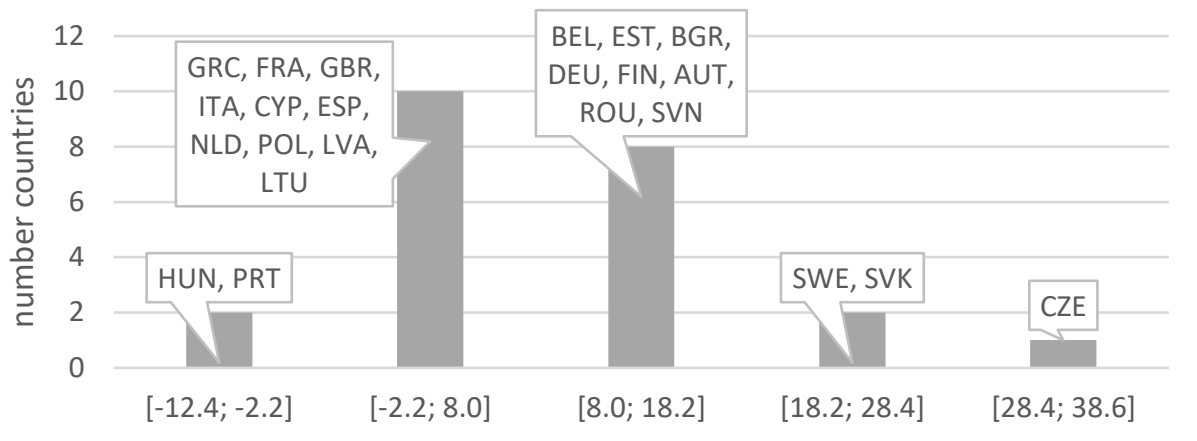

Source: Eurostat (2018), own elaboration

Positive Czech and Slovak evaluation of present and expected development in services is projected at the EU ranking for the whole period (see Figure 17 and Table 2b in the Annex). The differences in the average sentiment within the V4 countries are apparent from the frequency distribution in Figure 17. While the Czech and Slovak Republic are the EU leaders, Hungarian respondents - due to the above-mentioned pessimism caused by the macroeconomic imbalances - belong to the biggest pessimists in the EU28.

Figure 18 | SCl _differences between periods

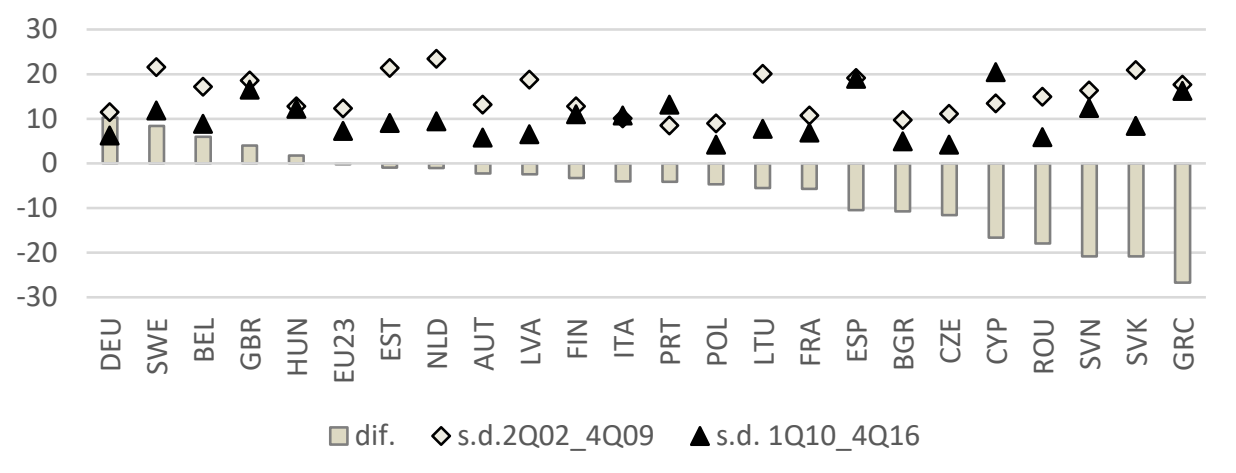

Source: Eurostat (2018), own elaboration

As Figure 18 shows, negative changes in average sentiment in services are apparent in 19 of the EU countries in the post-crisis period. Despite the relatively high decrease of Czech optimism, the Czech Republic has stayed the leader in SCl ranking and the position of Slovakia has worsened by two places (from $2^{\text {nd }}$ to $4^{\text {th }}$ rank). The slightly positive shift in the ranking for Hungary (from the $23^{\text {rd }}$ to $21^{\text {st }}$ place) and more important shift for Germany (from the $16^{\text {th }}$ to the $3^{\text {rd }}$ position) are caused by slightly lower average pessimism (Hungary) and higher optimism (Germany) in the post-crisis period. Deeper decreases of balances compared to their increases (and deeper negative changes compared to positive shifts for Hungary) are the reason for left skewness of $\mathrm{SCl}$ for the whole sample of countries during the pre-crisis period (see descriptive statistics in Table 8 in the Annex). In the post-crisis period, it is possible to observe lower standard deviation of $\mathrm{SCl}$ for all countries in our sample with the exception of Hungary (standard deviation for Hungarian $\mathrm{SCl}$ has stayed 
almost un-changed). As Table 3b (in the Annex) shows, GDP is relatively well correlated with the first lagged value of $\mathrm{SCl}$ in the pre-crisis period (with the exception of Poland) and with the second lagged value of $\mathrm{SCl}$ after the economic crisis (with the exception of the Czech Republic). Stronger correlation between variables is apparent in the pre-crisis period (with the exception of Poland). Higher correlation coefficients for the EU28 and the EU19 indicate that other EU countries (on average) have a stronger relationship between confidence indicators and GDP than the V4 and Germany.

\section{Conclusion}

We believe that the main reason for worse European results in competitiveness indicators based on soft data (compared to the regions of the developing world) lies in the so-called cultural bias (differences in cultural and national sentiment), particularly as it relates to the more negative sentiment in developed countries, especially in the post-crisis period. The changes in economic sentiment for the V4 countries and Germany in the period 2002Q2 2016Q4 were described using graphical examination and statistical analysis of ESI and confidence indicators. A key advantage of business surveys published by the European Commission is their periodicity and differentiation of respondents according to the important area of economy which was considered as a good tool for the aims of our analysis. These aims were to identify positive or negative trends in soft data and to verify the existence of (1) cultural bias (different national sentiment) in soft data and (2) the equivalent of the socalled halo effect (which is connected with the positive impacts of entry to the EU).

Graphical examination of ESI and confidence indicators implies more positive sentiment, or a lower rate of negativism, in the Czech Republic, Slovakia, and Poland in the pre-crisis period (the first period: 2002Q2-2009Q4, the second period: 2010Q1 - 2016Q4). Hungarian sentiment due to the impacts of macroeconomic imbalances which influenced Hungarian respondents in the first period showed improvement after the economic crisis. Macroeconomic performance of the V4 countries (measured by quarterly GDP growth) was above-average (inside the EU) in both time series, with a tendency to lower and more stable growth in the post-crisis period (see Table 4 in the Annex) in the Czech Republic, Poland, and Slovakia. In the EU28 as a whole, in the EU19 (Eurozone), in Germany, and Hungary, there was an apparent tendency to higher and more stable economic growth. In the post-crisis period, the development of ESI and confidence indicators were most probably influenced by the decrease of economic growth, acknowledgement of higher economic vulnerability, and the extinction of the positive expectations connected with etnry to the EU (the so-called halo effect). Despite the above-average economic performance of the Czech Republic, Poland, and Slovakia, these countries' average value of ESI was lower than the average value for the EU28 and the EU19. Differences between the average value of confidence indicators in the first and the second period indicate positive or negative changes in respondents' sentiment. In this respect, our analysis shows that the V4 countries are not a homogenous group of countries. In the Czech Republic, the decrease in all sentiment indicators was discovered in the post-crisis period.

The best position of the Czech Republic in international competitiveness rankings is probably connected with the above-average values of confidence indicators $(\mathrm{CCl}, \mathrm{ICl}, \mathrm{RCl}$, $\mathrm{SCI})$ compared to the EU28. Due to the negative sentiment in the first period connected with the country's macroeconomic imbalances, positive changes of sentiment (except for Constr. Cl) were observable in Hungary. Compared to the EU28, the above-average values 
of Hungarian sentiment were typical only for $\mathrm{ESI}, \mathrm{ICl}$, and $\mathrm{RCl}$. A different economic structure and less openness of the Polish economy had an impact on the differences in changes of economic sentiment in comparison with the answers of Czech and Slovak respondents. In the post-crisis period, improvements were apparent in $\mathrm{CCl}, \mathrm{RCl}$, and Constr. Cl, while deteriorations were found in $\mathrm{ESI}, \mathrm{ICI}$, and $\mathrm{SCl}$. Compared to the EU28, the below-average values of Polish sentiment were proved in all indicators. Apart from $\mathrm{CCI}$, deterioration in all confidence indicators was found in Slovakia. Compared to the EU28, the above-average values of Slovak sentiment were ascertained only for $\mathrm{ICl}, \mathrm{RCl}$, and $\mathrm{SCl}$. The rise of optimism in all sentiment indicators and above-average values (excepting $\mathrm{RCl}$ ) were proved in Germany.

Correlation analysis shows that all confidence indicators lagged behind the changes in GDP (by up to four quarters) and that the relationship between sentiment indicators and output varies across countries and sentiment measures. It seems that $\mathrm{CCI}$ is not as useful as ESI due to its weaker relationship with GDP swings. This finding corresponds with the results of the above-mentioned studies: consumer sentiment measures the degree of uncertainty felt by households, rather than just optimism or pessimism about the future.

\section{Acknowledgement}

This study was supported by the internal grant of Faculty of Business Administration, University of Economics, Prague (IP300040).

\section{References}

Blanchard, O. (1993). What caused the last recession? American Economic Review, 83(2), 270-274.

Browne, C., Geiger, T., \& Gutknecht, T. (2013). The executive opinion survey: The voice of the business community. The Global Competitiveness Report 2016-2017, 83-92.

Browne, C., Di Battista, A., Geiger, T., \& Verin, S. (2016). The executive opinion survey: The voice of the business community. The Global Competitiveness Report 2013-2014, 77-87.

Camerer, C. F., Loewenstein, G., \& Rabin, M. (Eds.) (2004). Advances in behavioral economics, Princeton University Press.

Claveria, O., Pons, E., \& Ramos, R. (2007). Business and consumer expectations and macroeconomic forecasts. International Journal of Forecasting, 23(1), 47-69.

Čihák, M., \& Mitra, S. (2009). The financial crisis and European emerging economies. Czech Journal of Economics and Finance (Finance a uver), 59(6), 541-553.

European Commission (2019). A User Manual to the Joint Harmonised EU Programme of Business and Consumer Surveys. Retrieved January 29, 2019, from https://ec.europa.eu/info/businesseconomy-euro/indicators-statistics/economic-databases/business-and-consumer-surveys_en.

Eurostat (2018). Database. Retrieved December 15, 2018, from https://ec.europa.eu/eurostat/databrowser/view/teibs010/default/table?lang=en

Gelper, S., \& Croux, C. (2010). On the construction of the European economic sentiment indicator. Oxford Bulletin of Economics and Statistics, 72(1), 47-62.

Hauner, D., Jonas, J., \& Kumar, M. (2007). Policy Credibility and Sovereign Credit-The Case of New EU Member States. IMF Working Paper No. WP/07/1, Washington: International Monetary Fund. 
Jansen, W. J., \& Nahuis, N. J. (2003). The stock market and consumer confidence: European evidence. Economics Letters, 79(1), 89-98.

Katona, G. (1951). Psychological analysis of economic behavior. New York: McGraw-Hill Book Company Inc.

Keynes, J. M. (1973). The general theory of employment, interest and money. Collected Writings of John Maynard Keynes, Vol. 7, London: St. Martin's Press for the Royal Economic Society.

Koppl, R. (1991). Retrospectives: animal spirits. Journal of Economic Perspectives, 5(3), 203-210.

Lemmens, A., Croux, C., \& Dekimpe, M. G. (2005). On the predictive content of production surveys: A pan-European study. International Journal of Forecasting, 21(2), 363-375.

Lemmens, A., Croux, C., \& Dekimpe, M. G. (2007). Consumer confidence in Europe: United in diversity? International Journal of Research in Marketing, 24(2), 113-127.

Ludvigson, S. C. (2004). Consumer confidence and consumer spending. Journal of Economic perspectives, 18(2), 29-50.

Nečadová, M., \& Soukup, J. (2013). Kontroverzní pojem národní konkurenceschopnost a výsledky zemi V-4 v mezinárodních žebřičcích konkurenceschopnosti 2007-2012. Politická ekonomie, 61(5), 583-604.

Nečadová, M. (2015). Selected Approaches to Measurement of National Competitiveness and the Results. Acta Oeconomica Pragensia, 2015(2), 22-39.

Neisingh, P., Stokman, A. (2013). What Drives Consumer Confidence in Times of Financial Crises? Evidence for the Netherlands. De Nederlandsche Bank. Working Paper No. 394, https://doi.org/10.2139/ssrn.2338977

Ochel, W., Röhn, O. (2006). Ranking of Countries - The WEF, IMD, Fraser and Heritage Indices, CESifo DICE Report, 4(2), 48-60.

Pošta, V., \& Valenta, V. (2011). Composite Leading Indicators Based on Business Surveys: Case of the Czech Economy. Statistika: Statistics and Economy Journal, 48(1), 12-18.

Pošta, V., \& Pikhart, Z. (2012). The Use of the Sentiment Economic Indicator for GDP Forecasting: Evidence from EU Economies. Statistika: Statistics and Economy Journal, 49(1), 41-55.

Roberts, I., \& Simon, J. (2001). What do sentiment surveys measure?. Reserve Bank of Australia.

Santero, T., \& Westerlund, N. (1996). Confidence Indicators and Their Relationship to Changes in Economic Activity. OECD Economics Department Working Papers, No. 170, OECD Publishing, Paris, https://doi-org.zdroje.vse.cz/10.1787/537052766455.

Sorić, P., Lolić, I., \& Čižmešija, M. (2016). European economic sentiment indicator: an empirical reappraisal. Quality \& Quantity, 50(5), 2025-2054.

Throop, A. W. (1992). Consumer sentiment: Its causes and effects. Federal Reserve Bank of San Francisco Economic Review, 1, 35-59.

World Economic Forum (2017). The Global Competitivness Report 2017-18. Retrieved January, 20, 2019, from http://www3.weforum.org/docs/GCR20172018/05FullReport/TheGlobalCompetitivenessReport2017\%E2\%80\%932018.pdf.

The research paper has been reviewed. | Received: March 21, 2019; Revised: July 12, 2019; Accepted: September 2, 2019; Prepublished online: September 2, 2019; Published: December 17, 2019 


\section{Annex}

Table 1 | Variables covered in the monthly business and consumer surveys

\begin{tabular}{|c|c|c|c|}
\hline $\begin{array}{l}\text { Type of } \\
\text { survey }\end{array}$ & Monthly questions & $\begin{array}{l}\text { Type of } \\
\text { survey }\end{array}$ & Monthly questions \\
\hline \multirow{7}{*}{ Industry } & Production, past 3 months & \multirow{3}{*}{ Services } & $\begin{array}{l}\text { Firm's employment, past } 3 \\
\text { months }\end{array}$ \\
\hline & Production, next 3 months & & $\begin{array}{l}\text { Firm's employment, next } 3 \\
\text { months }\end{array}$ \\
\hline & Total order books & & Selling prices, next 3 months \\
\hline & Export order books & \multirow{5}{*}{$\begin{array}{l}\text { Financial } \\
\text { services }\end{array}$} & $\begin{array}{l}\text { Business situation, past } 3 \\
\text { months }\end{array}$ \\
\hline & Stocks of finished products & & $\begin{array}{l}\text { Demand/turnover, past } 3 \\
\text { months }\end{array}$ \\
\hline & Selling prices, next 3 months & & $\begin{array}{l}\text { Demand/Turnover, next } 3 \\
\text { months }\end{array}$ \\
\hline & $\begin{array}{l}\text { Firm's employment, next } 3 \\
\text { months }\end{array}$ & & $\begin{array}{l}\text { Firm's employment, past } 3 \\
\text { months }\end{array}$ \\
\hline \multirow{5}{*}{ Construction } & Building activity, past 3 months & & $\begin{array}{l}\text { Firm's employment, next } 3 \\
\text { months }\end{array}$ \\
\hline & Factors limiting building activity & \multirow{12}{*}{ Consumers } & $\begin{array}{l}\text { Financial situation, past } 12 \\
\text { months }\end{array}$ \\
\hline & Overall order books & & $\begin{array}{l}\text { Financial situation, next } 12 \\
\text { months }\end{array}$ \\
\hline & $\begin{array}{l}\text { Firm's employment, next } 3 \\
\text { months }\end{array}$ & & $\begin{array}{l}\text { General economic situation, } \\
\text { past } 12 \text { months }\end{array}$ \\
\hline & Selling prices, next 3 months & & $\begin{array}{l}\text { General economic situation, } \\
\text { next } 12 \text { months }\end{array}$ \\
\hline \multirow{6}{*}{ Retail trade } & Business activity, past 3 months & & $\begin{array}{l}\text { Consumer prices, past } 12 \\
\text { months }\end{array}$ \\
\hline & Business activity, next 3 months & & $\begin{array}{l}\text { Consumer prices, next } 12 \\
\text { months }\end{array}$ \\
\hline & Stocks of goods & & $\begin{array}{l}\text { Unemployment, next } 12 \\
\text { months }\end{array}$ \\
\hline & $\begin{array}{l}\text { Orders placed with suppliers, } \\
\text { next } 3 \text { months }\end{array}$ & & $\begin{array}{l}\text { Major purchases of durable } \\
\text { consumer goods, current } \\
\text { environment }\end{array}$ \\
\hline & $\begin{array}{l}\text { Firm's employment, next } 3 \\
\text { months }\end{array}$ & & $\begin{array}{l}\text { Major purchases intentions, } \\
\text { next } 12 \text { months }\end{array}$ \\
\hline & Selling prices, next 3 months & & Savings, current environment \\
\hline \multirow{3}{*}{ Services } & $\begin{array}{l}\text { Business situation, past } 3 \\
\text { months }\end{array}$ & & $\begin{array}{l}\text { Savings intentions, next } 12 \\
\text { months }\end{array}$ \\
\hline & $\begin{array}{l}\text { Demand/Turnover, past } 3 \\
\text { months }\end{array}$ & & Capacity to save \\
\hline & $\begin{array}{l}\text { Demand/Turnover, next } 3 \\
\text { months }\end{array}$ & & \\
\hline
\end{tabular}

Source: European Commision (2019), own elaboration 
Table 2a | EU28 - countries' ranking in three periods (according to means) ( $A=$ 2002Q2-2016Q4, $B=2002 Q 2-2009 Q 4, C=2010 Q 1-2016 Q 4)$

\begin{tabular}{|c|c|c|c|c|c|c|c|c|c|c|c|c|}
\hline & \multicolumn{3}{|c|}{ qGDP } & \multicolumn{3}{|c|}{ ESI } & \multicolumn{3}{|c|}{$\mathrm{CCl}$} & \multicolumn{3}{|c|}{ ICI } \\
\hline & A & B & C & $\mathbf{A}$ & B & C & A & B & C & $A$ & B & C \\
\hline AUT & 17 & 20 & 17 & 16 & 14 & 10 & 4 & 4 & 6 & 14 & 14 & 15 \\
\hline BEL & 16 & 18 & 18 & 14 & 18 & 9 & 8 & 6 & 9 & 19 & 19 & 17 \\
\hline BGR & 6 & 3 & 11 & 5 & 1 & 16 & 24 & 22 & 24 & 8 & 6 & 13 \\
\hline HRV & 18 & 10 & 24 & $x$ & $x$ & $x$ & $x$ & $x$ & $x$ & $x$ & $x$ & $x$ \\
\hline CYP & 19 & 8 & 27 & 17 & 4 & 24 & 23 & 23 & 23 & 13 & 4 & 22 \\
\hline CZE & 11 & 7 & 14 & 6 & 2 & 11 & 10 & 8 & 10 & 2 & 2 & 2 \\
\hline DNK & 25 & 26 & 16 & 7 & 13 & 8 & 3 & 2 & 2 & 6 & 9 & 6 \\
\hline EST & 9 & 9 & 4 & 2 & 7 & 7 & 7 & 9 & 7 & 1 & 1 & 3 \\
\hline FIN & 23 & 21 & 22 & 13 & 10 & 12 & 1 & 1 & 3 & 7 & 5 & 14 \\
\hline FRA & 24 & 24 & 21 & 15 & 11 & 13 & 15 & 13 & 18 & 20 & 20 & 18 \\
\hline DEU & 22 & 25 & 13 & 18 & 25 & 2 & 6 & 10 & 4 & 16 & 22 & 9 \\
\hline GRC & 28 & 13 & 28 & 25 & 12 & 25 & 25 & 25 & 25 & 22 & 11 & 24 \\
\hline HUN & 14 & 19 & 15 & 10 & 22 & 3 & 22 & 24 & 20 & 11 & 17 & 4 \\
\hline IRL & 1 & 14 & 1 & $x$ & $x$ & $x$ & 12 & 19 & 11 & $x$ & $x$ & $x$ \\
\hline ITA & 27 & 28 & 25 & 19 & 17 & 17 & 16 & 14 & 17 & 15 & 13 & 16 \\
\hline LVA & 7 & 6 & 7 & 3 & 9 & 5 & 14 & 15 & 12 & 10 & 8 & 12 \\
\hline LTU & 3 & 5 & 3 & 1 & 5 & 6 & 11 & 11 & 14 & 18 & 16 & 19 \\
\hline LUX & 10 & 12 & 5 & 21 & 16 & 23 & $x$ & $x$ & $x$ & 25 & 25 & 25 \\
\hline MLT & 8 & 16 & 2 & $x$ & $x$ & $x$ & $x$ & $x$ & $x$ & $x$ & $x$ & $x$ \\
\hline NLD & 21 & 22 & 20 & 22 & 23 & 14 & 5 & 5 & 5 & 9 & 12 & 11 \\
\hline POL & 4 & 4 & 6 & 23 & 20 & 21 & 18 & 17 & 16 & 24 & 24 & 23 \\
\hline PRT & 26 & 27 & 26 & 24 & 24 & 22 & 21 & 21 & 21 & 21 & 18 & 20 \\
\hline ROU & 5 & 2 & 10 & 12 & 3 & 20 & 20 & 20 & 22 & 5 & 7 & 10 \\
\hline SVK & 2 & 1 & 9 & 9 & 6 & 18 & 17 & 18 & 15 & 3 & 3 & 1 \\
\hline SVN & 13 & 11 & 19 & 8 & 8 & 15 & 19 & 16 & 19 & 4 & 10 & 5 \\
\hline ESP & 20 & 15 & 23 & 20 & 19 & 19 & 13 & 12 & 13 & 23 & 21 & 21 \\
\hline SWE & 12 & 17 & 8 & 4 & 15 & 1 & 2 & 3 & 1 & 12 & 15 & 7 \\
\hline GBR & 15 & 23 & 12 & 11 & 21 & 4 & 9 & 7 & 8 & 17 & 23 & 8 \\
\hline
\end{tabular}

Source: Eurostat (2018), own elaboration 
Table 2b| EU28 - countries' ranking in three periods (according to means) (A= 2002Q2-2016Q4, B = 2002Q2-2009Q4, C=2010Q1-2016Q4)

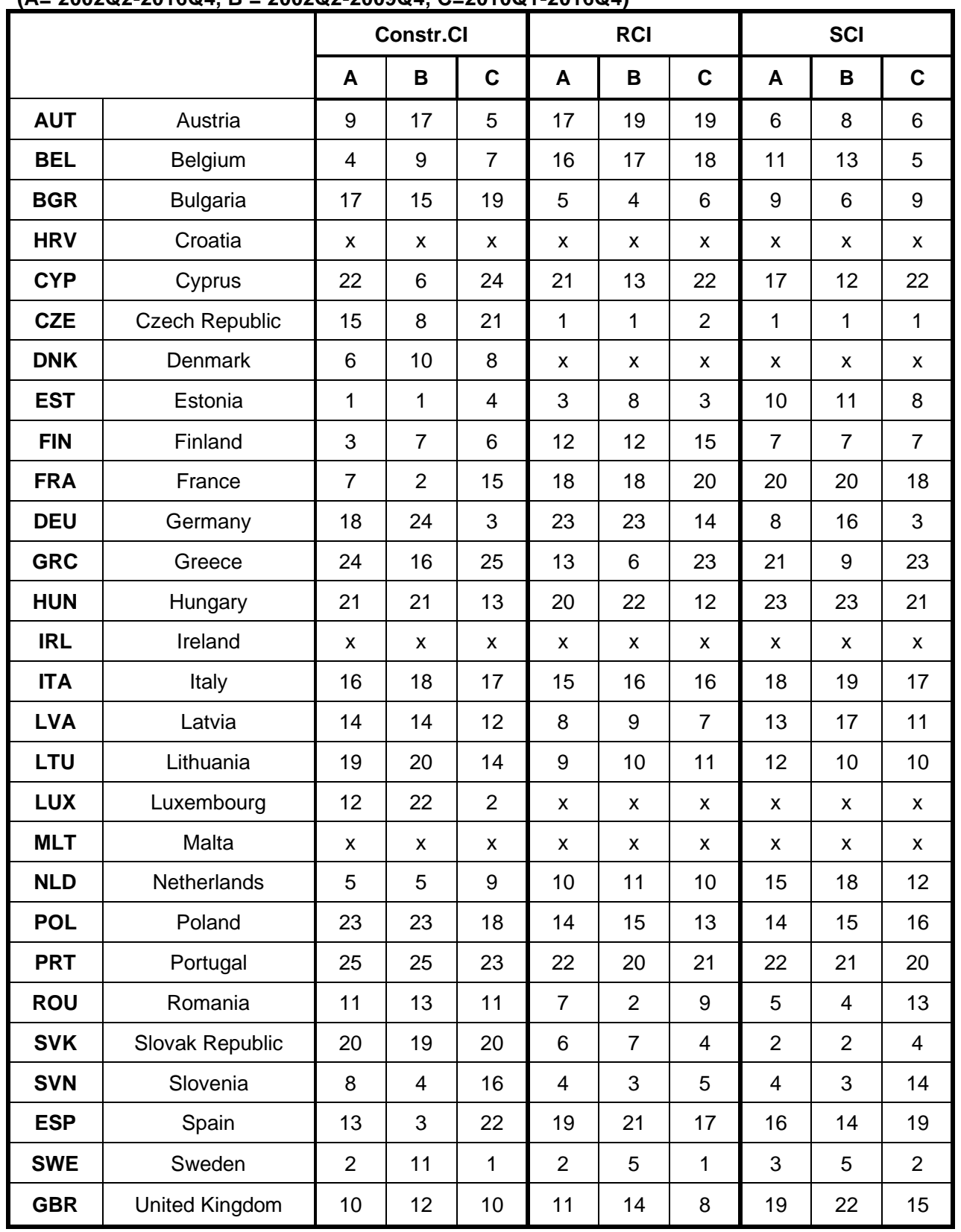

Source: Eurostat (2018), own elaboration 
Table 3a| Correlation coefficients (sentiment/confident indicator vs. quarterly GDP growth) (A= 2002Q2-2016Q4, B = 2002Q2-2009Q4, C=2010Q1-2016Q4)

\begin{tabular}{|l|c|c|c|c|c|c|c|c|c|}
\hline & \multicolumn{3}{|c|}{ ESI } & \multicolumn{3}{c|}{ CCI } & \multicolumn{3}{c|}{ ICI } \\
\hline & $\begin{array}{c}\mathbf{A} \\
\text { GDPt-1 }\end{array}$ & $\begin{array}{c}\mathbf{B} \\
\text { GDPt-1 }\end{array}$ & $\begin{array}{c}\mathbf{C} \\
\text { GDPt-2 }\end{array}$ & $\begin{array}{c}\mathbf{A} \\
\text { GDPt-1 }\end{array}$ & $\begin{array}{c}\mathbf{B} \\
\text { GDPt-1 }\end{array}$ & $\begin{array}{c}\mathbf{C} \\
\text { GDPt-1 }\end{array}$ & $\begin{array}{c}\text { A } \\
\text { GDPt-1 }\end{array}$ & $\begin{array}{c}\text { B } \\
\text { GDPt-1 }\end{array}$ & $\begin{array}{c}\mathbf{C} \\
\text { GDPt-2 }\end{array}$ \\
\hline EU28 & $\mathbf{0 . 8 4 4}$ & $\mathbf{0 . 8 7 4}$ & $\mathbf{0 . 7 9 2}$ & $\mathbf{0 . 7 4 9}$ & $\mathbf{0 . 8 5 2}$ & 0.695 & $\mathbf{0 . 8 1 9 ^ { * }}$ & $\mathbf{0 . 8 5 3}$ & $\mathbf{0 . 8 0 2}$ \\
\hline EU19 & $\mathbf{0 . 8 3 4}$ & $\mathbf{0 . 8 5 9}$ & $\mathbf{0 . 8 1 3}$ & $\mathbf{0 . 7 5 2}$ & $\mathbf{0 . 8 2 2}$ & $\mathbf{0 . 7 3 7}$ & $\mathbf{0 . 8 0 9}$ & $\mathbf{0 . 8 3 9}$ & $\mathbf{0 . 7 9 7}$ \\
\hline DEU & 0.669 & 0.725 & 0.638 & $0.609^{\star}$ & 0.681 & $0.592^{*}$ & $0.706^{*}$ & 0.729 & 0.662 \\
\hline CZE & $\mathbf{0 . 7 8 0}$ & $\mathbf{0 . 8 0 0}$ & $\mathbf{0 . 7 6 5}$ & 0.566 & 0.546 & $0.648^{*}$ & $\mathbf{0 . 7 6 4}$ & $\mathbf{0 . 7 9 0}$ & 0.688 \\
\hline HUN & 0.648 & 0.786 & 0.538 & 0.585 & 0.640 & 0.479 & 0.545 & 0.683 & 0.576 \\
\hline POL & $0.531^{*}$ & $0.497^{\star}$ & 0.501 & 0.285 & 0.313 & 0.225 & $0.579^{\star}$ & $0.557^{\star}$ & 0.591 \\
\hline SVK & 0.571 & 0.572 & 0.657 & 0.352 & 0.395 & 0.518 & $0.527^{\star}$ & 0.525 & 0.663 \\
\hline
\end{tabular}

Source: Eurostat (2018), own elaboration

Notes: number of * or ${ }^{x}$ indicates the different number of lags compared to table heading ( ${ }^{*}$ means one more lag of sentiment indicator in a given country, ${ }^{* *}$ means two more lags of the sentiment indicator in a given country, ${ }^{x}$ means one less lag of sentiment indicator in a given country)

Table 3b| Correlation coefficients (sentiment/confident indicator vs. quarterly GDP growth) (A= 2002Q2-2016Q4, B = 2002Q2-2009Q4, C=2010Q1-2016Q4)

\begin{tabular}{|l|c|c|c|c|c|c|c|c|c|}
\hline & \multicolumn{3}{|c}{ Constr.CI } & \multicolumn{3}{c|}{ RCI } & \multicolumn{3}{c|}{ SCI } \\
\hline & $\begin{array}{c}\text { A } \\
\text { GDPt-2 }\end{array}$ & $\begin{array}{c}\text { G } \\
\text { GDPt-2 }\end{array}$ & $\begin{array}{c}\text { C } \\
\text { GDPt-2 }\end{array}$ & $\begin{array}{c}\text { A } \\
\text { GDPt-1 }\end{array}$ & $\begin{array}{c}\text { B } \\
\text { GDPt-1 }\end{array}$ & $\begin{array}{c}\text { C } \\
\text { GDPt-2 }\end{array}$ & $\begin{array}{c}\text { A } \\
\text { GDPt-1 }\end{array}$ & $\begin{array}{c}\text { B } \\
\text { GDPt-1 }\end{array}$ & $\begin{array}{c}\text { C } \\
\text { GDPt-2 }\end{array}$ \\
\hline EU28 & 0.641 & $\mathbf{0 . 8 3 7}$ & $0.526^{* *}$ & 0.698 & $\mathbf{0 . 7 6 3}$ & $\mathbf{0 . 7 5 6 *}$ & $\mathbf{0 . 8 1 3}$ & $\mathbf{0 . 8 4 8}$ & $\mathbf{0 . 7 6 9}$ \\
\hline EU19 & 0.570 & $\mathbf{0 . 8 0 6}$ & $0.607^{* *}$ & 0.647 & 0.699 & $\mathbf{0 . 7 8 7}$ & $\mathbf{0 . 7 9 9}$ & $\mathbf{0 . 8 3 6}$ & $\mathbf{0 . 8 0 9}$ \\
\hline DEU & 0.234 & $0.320^{* *}$ & $-0.138^{* *}$ & 0.415 & $0.472^{*}$ & 0.634 & 0.573 & 0.632 & 0.500 \\
\hline CZE & $0.620^{*}$ & $\mathbf{0 . 8 1 8 ^ { * }}$ & $0.719^{*}$ & $0.742^{* *}$ & $0.73^{* * *}$ & $\mathbf{0 . 7 6 5 *}$ & $0.737^{*}$ & $\mathbf{0 . 7 6 9}$ & $0.634^{* *}$ \\
\hline HUN & 0.643 & $\mathbf{0 . 7 5 3}$ & 0.548 & $0.401^{*}$ & 0.627 & 0.586 & 0.672 & $\mathbf{0 . 8 0 1}$ & 0.523 \\
\hline POL & $0.425^{* *}$ & $0.478^{* *}$ & 0.544 & $0.41^{* * *}$ & $0.534^{* *}$ & 0.461 & $0.502^{* *}$ & $0.49^{* * *}$ & 0.498 \\
\hline SVK & 0.410 & 0.512 & 0.578 & $0.426^{*}$ & 0.495 & $\mathbf{0 . 8 2 7 ^ { * * }}$ & 0.434 & 0.442 & $0.313^{* *}$ \\
\hline
\end{tabular}

Source: Eurostat (2018), own elaboration

Notes: number of ${ }^{*}$ or ${ }^{*}$ indicates the different number of lags compared to table heading $\left({ }^{*}\right.$ means one more lag of sentiment indicator in a given country, ${ }^{* *}$ means two more lags of the sentiment indicator in a given country, ${ }^{x}$ means one less lag of sentiment indicator in a given country) 
Table 4 | Quarterly GDP growth - descriptive statistics

\begin{tabular}{|l|c|c|c|c|c|c|c|c|c|c|}
\hline Period & \multicolumn{5}{|c|}{ B (2002Q2_2009Q4) } & \multicolumn{5}{c|}{ C (2010Q1_2016Q4) } \\
\hline & Mean & Med. & s.d. & Min & Max & Mean & Med. & s.d. & Min & Max \\
\hline EU28 & 0.31 & 0.6 & 0.784 & -2.6 & 1.0 & 0.332 & 0.40 & 0.319 & -0.4 & 1.0 \\
\hline EU19 & 0.245 & 0.5 & 0.81 & -3.0 & 1.1 & 0.268 & 0.35 & 0.356 & -0.4 & 1.0 \\
\hline CZE & 0.835 & 1.0 & 1.14 & -3.7 & 2.3 & 0.457 & 0.4 & 0.62 & -0.8 & 1.5 \\
\hline DEU & 0.148 & 0.4 & 1.1 & -4.5 & 1.6 & 0.475 & 0.4 & 0.533 & -0.5 & 2.1 \\
\hline HUN & 0.403 & 0.7 & 1.23 & -4.0 & 1.5 & 0.439 & 0.6 & 0.706 & -2.3 & 1.4 \\
\hline POL & 1.1 & 1.2 & 0.797 & -0.5 & 2.4 & 0.782 & 1.0 & 0.554 & -0.3 & 1.7 \\
\hline SVK & 1.31 & 1.6 & 2.3 & -9.1 & 6.1 & 0.693 & 0.65 & 0.292 & 0.1 & 1.3 \\
\hline
\end{tabular}

Source: Eurostat (2018), own elaboration

Table 5| Economic sentiment indicator (ESI) - descriptive statistics

\begin{tabular}{|l|c|c|c|c|c|c|c|c|c|c|}
\hline Period & \multicolumn{5}{|c|}{ B (2002Q2_2009Q4) } & \multicolumn{5}{c|}{ C (2010Q1_2016Q4) } \\
\hline & Mean & Med. & s.d. & Min & Max & Mean & Med. & s.d. & Min & Max \\
\hline EU28 & 98.7 & 100.2 & 11.4 & 67.5 & 114.1 & 100.6 & 103.9 & 6.58 & 87.3 & 107.8 \\
\hline EU19 & 98.3 & 99.9 & 10.6 & 69.9 & 112.9 & 99.6 & 101.3 & 6.31 & 86.3 & 108.4 \\
\hline CZE & 105.7 & 107.6 & 9.77 & 79 & 116.6 & 98.6 & 99.5 & 6.01 & 88.9 & 108.4 \\
\hline DEU & 94.3 & 94.8 & 9.89 & 71.5 & 110.6 & 105 & 104.6 & 5.41 & 94 & 116 \\
\hline HUN & 98.1 & 99.2 & 10.4 & 69.5 & 112.5 & 104 & 105.4 & 9.27 & 88.7 & 115.3 \\
\hline POL & 99.3 & 97.6 & 11.1 & 80.3 & 118.1 & 96.1 & 97.8 & 4.61 & 86.3 & 101.4 \\
\hline SVK & 104 & 106.8 & 12.5 & 68 & 117.8 & 97.6 & 98.8 & 4.82 & 86.6 & 103 \\
\hline
\end{tabular}

Source: Eurostat (2018), own elaboration 
Table 6 | Consumer confidence indicator $(\mathrm{CCl})$ - descriptive statistics

\begin{tabular}{|l|c|c|c|c|c|c|c|c|c|c|}
\hline Period & \multicolumn{5}{|c|}{ B (2002Q2_2009Q4) } & \multicolumn{5}{c|}{ C (2010Q1_2016Q4) } \\
\hline & Mean & Med. & s.d. & Min & Max & Mean & Med. & s.d. & Min & Max \\
\hline EU28 & -12.8 & -11.5 & 6.6 & -31.8 & -2.6 & -12.1 & -12 & 6.39 & -24 & -3.4 \\
\hline EU19 & -14.4 & -13.9 & 6.79 & -32.8 & -2.5 & -13.4 & -11.4 & 6.09 & -26 & -5.2 \\
\hline CZE & -8.2 & -7.8 & 7.83 & -26.1 & 2.6 & -10.7 & -10.8 & 11.62 & -28.4 & 5.5 \\
\hline DEU & -11.7 & -14.6 & 9.48 & -31.4 & 8.9 & -1.5 & -1.3 & 5.69 & -16.1 & 9.1 \\
\hline HUN & -34.4 & -29.2 & 17.61 & -66.1 & -1.1 & -29.7 & -24.3 & 11.81 & -50.2 & -15.9 \\
\hline POL & -20 & -21.6 & 11.17 & -36.5 & -1.9 & -19.8 & -20 & 6.99 & -31.3 & -7.9 \\
\hline SVK & -20 & -18.1 & 13.22 & -40.9 & 3.3 & -19.5 & -19.2 & 9.11 & -35.4 & -6.1 \\
\hline
\end{tabular}

Source: Eurostat (2018), own elaboration

Table 7| Industrial confidence indicator (ICl) - descriptive statistics

\begin{tabular}{|l|c|c|c|c|c|c|c|c|c|c|}
\hline Period & \multicolumn{5}{|c|}{ B (2002Q2_2009Q4) } & \multicolumn{5}{c|}{ C (2010Q1_2016Q4) } \\
\hline & Mean & Med. & s.d. & Min & Max & Mean & Med. & s.d. & Min & Max \\
\hline EU28 & -7.2 & -5.2 & 10.9 & -35.7 & 7 & -4.5 & -3.1 & 4.83 & -13.9 & 5.8 \\
\hline EU19 & -7 & -6.1 & 11.1 & -35.7 & 7.4 & -4.9 & -3.8 & 5.2 & -15.3 & 6.5 \\
\hline CZE & 4 & 8.6 & 12.7 & -32.8 & 17.2 & 0.9 & 2.3 & 6.03 & -10.4 & 13.2 \\
\hline DEU & -9.1 & -7 & 13.7 & -40.7 & 10.2 & -1.7 & -2.3 & 7.06 & -14.7 & 14.5 \\
\hline HUN & -7.4 & -5.1 & 8.16 & -32.1 & 2.5 & 0.1 & 2.5 & 5.73 & -10.1 & 7.1 \\
\hline POL & -12.1 & -11.9 & 7.16 & -27.5 & -1 & -13.7 & -12.8 & 2.71 & -20.2 & -10.9 \\
\hline SVK & 3.6 & 8.4 & 11.6 & -29.5 & 17.3 & 1.2 & 2.2 & 4.87 & -12.5 & 10.9 \\
\hline
\end{tabular}

Source: Eurostat (2018), own elaboration 
Table 8 Retail confidence indicator $(\mathrm{RCl})$ - descriptive statistics

\begin{tabular}{|l|c|c|c|c|c|c|c|c|c|c|}
\hline Period & \multicolumn{4}{|c|}{ B (2Q2002_4Q2009) } & \multicolumn{5}{c|}{ C (1Q2010_4Q2016) } \\
\hline & Mean & Med. & s.d. & Min & Max & Mean & Med. & s.d. & Min & Max \\
\hline EU28 & -6.2 & -6.4 & 7.42 & -24.2 & 6.6 & -2.3 & -0.6 & 6.54 & -12.8 & 8 \\
\hline EU19 & -8.6 & -10.4 & 6.46 & -20.8 & 3.4 & -5.1 & -3.1 & 6.77 & -16.8 & 5.1 \\
\hline CZE & 19.4 & 19.5 & 6.12 & 1.9 & 28.8 & 13 & 12.7 & 4.99 & 2.9 & 21.7 \\
\hline DEU & -19.1 & -21.3 & 9.29 & -33.7 & -2.2 & -3 & -2.8 & 6.43 & -15.6 & 11.1 \\
\hline HUN & -15.7 & -13.9 & 7.85 & -32.8 & -3.9 & -0.9 & 0.5 & 9.11 & -16.1 & 10.5 \\
\hline POL & -3.7 & -6.1 & 7.57 & -12.9 & 10.9 & -2.6 & -1.5 & 3.71 & -10 & 1.9 \\
\hline SVK & 10.8 & 13.8 & 12.7 & -21.5 & 27 & 9.5 & 10.1 & 6.78 & -9.8 & 20 \\
\hline
\end{tabular}

Source: Eurostat (2018), own elaboration

Table 9| Construction confidence indicator (Constr. $\mathrm{Cl}$ ) - descriptive statistics

\begin{tabular}{|l|c|c|c|c|c|c|c|c|c|c|}
\hline Period & \multicolumn{5}{|c|}{ B (2002Q2_2009Q4) } & \multicolumn{5}{c|}{ C (2010Q1_2016Q4) } \\
\hline & Mean & Med. & s.d. & Min & Max & Mean & Med. & s.d. & Min & Max \\
\hline EU28 & -11.6 & -10.1 & 12.2 & -38.9 & 3.4 & -23.9 & -25 & 5.91 & -33.3 & -11.5 \\
\hline EU19 & -11 & -10.9 & 11.1 & -36 & 4.1 & -24.5 & -24.9 & 4.35 & -30.5 & -13.1 \\
\hline CZE & -6.2 & -3.5 & 9.53 & -35 & 3.7 & -35.2 & -38.8 & 11.1 & -53.5 & -16.1 \\
\hline DEU & -35.3 & -31 & 12.5 & -52.9 & -14.1 & -9.1 & -8.7 & 6.36 & -26.4 & 4.0 \\
\hline HUN & -22.5 & -18.9 & 13.1 & -53.6 & -3 & -26 & -26.9 & 15.0 & -46.7 & -3.5 \\
\hline POL & -31.2 & -34.4 & 20.1 & -65.6 & -1.7 & -29.4 & -28.1 & 5.69 & -40.5 & -23.0 \\
\hline SVK & -15.9 & -13.4 & 13.8 & -51.9 & 2.9 & -32.4 & -37.5 & 16.2 & -56 & -1.5 \\
\hline
\end{tabular}

Source: Eurostat (2018), own elaboration 
Table 10| Service confidence indicator (SCl) - descriptive statistics

\begin{tabular}{|l|c|c|c|c|c|c|c|c|c|c|}
\hline Period & \multicolumn{5}{|c|}{ B (2002Q2_2009Q4) } & \multicolumn{5}{c|}{ C (2010Q1_2016Q4) } \\
\hline & Mean & Med. & s.d. & Min & Max & Mean & Med. & s.d. & Min & Max \\
\hline EU28 & 4.1 & 7.7 & 12.3 & -26.7 & 18.9 & 3.9 & 7 & 7.29 & -11.2 & 13.5 \\
\hline EU19 & 4.6 & 7.7 & 11.3 & -22.6 & 18.7 & 3.6 & 5 & 7.14 & -10.4 & 12.6 \\
\hline CZE & 39 & 43 & 11.1 & 10 & 50 & 27.3 & 26.7 & 4.22 & 19 & 36.7 \\
\hline DEU & 5.5 & 8.8 & 11.5 & -19.2 & 20 & 15.7 & 15 & 6.24 & 4 & 27.7 \\
\hline HUN & -8.1 & -5.8 & 12.8 & -40.1 & 9.7 & -6.4 & -7.9 & 12.3 & -25.9 & 9.5 \\
\hline POL & 5.5 & 3.4 & 8.9 & -9.0 & 22.2 & 1.1 & 0.4 & 4.18 & -6.8 & 8.6 \\
\hline SVK & 34.2 & 42.0 & 20.9 & -20.9 & 57.7 & 13.4 & 14.2 & 8.34 & -0.8 & 31.5 \\
\hline
\end{tabular}

Source: Eurostat (2018), own elaboration 